\title{
Putting the "Co" in Education: Timing, Reasons, and Consequences of College Coeduction from 1835 to the Present
}

\section{Citation}

Goldin, Claudia and Lawrence F. Katz. Putting the "co" in education: timing, reasons, and consequences of college coeduction from 1835 to the Present. 2011. Journal of Human Capital 5(4): 377-417.

\section{Published Version}

doi:10.1086/663277

\section{Permanent link}

http://nrs.harvard.edu/urn-3:HUL.InstRepos:8642950

\section{Terms of Use}

This article was downloaded from Harvard University's DASH repository, and is made available under the terms and conditions applicable to Open Access Policy Articles, as set forth at http:// nrs.harvard.edu/urn-3:HUL.InstRepos:dash.current.terms-of-use\#OAP

\section{Share Your Story}

The Harvard community has made this article openly available.

Please share how this access benefits you. Submit a story.

\section{Accessibility}


October 2, 2011

Putting the 'Co' in Education:

Timing, Reasons, and Consequences of College Coeducation from 1835 to the Present

\author{
Claudia Goldin \\ Lawrence F. Katz \\ Department of Economics \\ Harvard University \\ and \\ National Bureau of Economic Research
}

Bernie Zipprich provided exceptional research assistance on all parts of the project and Ryan Sakoda followed in turn. Julia Fifer helped with the coding of the coeducation data set, and Janet Currie and Louis Galambos supplied some of the coeducation dates. Emily Glassberg Sands assisted with the references. Helpful comments on a draft were offered by Stanley Engerman, Julie Reuben, Emily Glassberg Sands, members of the NBER-DAE 2010 Summer Institute and the Harvard Economic History Workshop. We thank them all. We are grateful to the editor of the Journal of Human Capital and an anonymous referee for further comments. 


\begin{abstract}
The history of coeducation in U.S. higher education is explored through an analysis of a database containing information on all institutions offering four-year undergraduate degrees that operated in 1897, 1924, 1934, or 1980, most of which still exist today. These data reveal surprises about the timing of coeducation and the reasons for its increase. Rather than being episodic and caused by financial pressures brought about by wars and recessions, the process of switching from single-sex to coeducational colleges was relatively continuous from 1835 to the $1950 \mathrm{~s}$ before it accelerated (especially for Catholic institutions) in the 1960s and 1970s. We explore the empirical implications of a model of switching from single-sex education to coeducation in which schools that become coeducational lose donations from existing alumni. But by raising the quality of new students, a switch to coeducation increases other future revenues. We find that older and private single-sex institutions were slower to become coeducational and that institutions persisting as single sex into the 1970s had lower enrollment growth in the late 1960s and early 1970s than those that switched earlier. We also find that access to coeducational institutions in the first half of the twentieth century was associated with increased women's educational attainment. Coeducation mattered to women's education throughout U.S. history and it mattered to a greater extent in the more distant past than in the more recent and celebrated period of change.
\end{abstract}


Women now receive 57 percent of all BAs in the United States and 97 percent of them are awarded by coeducational institutions, defined here as institutions that admit both males and females and in which both can take classes together. ${ }^{1}$ Although almost all undergraduates in the United States today attend a coeducational institution, none could have prior to the appearance of the first such college around 1835. When did institutions of higher education become coeducational, why did they, and what was the impact of coeducation on women's educational attainment?

These subjects are explored through an analysis of a database containing information on all institutions of higher education offering four-year undergraduate degrees that operated in 1897, 1924, or 1934, most of which still exist today. ${ }^{2}$ Data on all four-year institutions in 1980 that were founded from 1934 to 1980, or established as four-year institutions during that period, are added to the database. These data reveal some surprises about the timing of coeducation and the reasons for its increase. ${ }^{3}$

We find that the founding of coeducational institutions in the public and private sectors occurred at a fairly steady rate from 1835 to 1980 . In addition, the rate of switching from singlesex to coeducational status was also relatively continuous from the $1860 \mathrm{~s}$ through the $1950 \mathrm{~s}$. Although the rate of switching increased considerably in the 1960s and 1970s, the jump was greatest for Catholic single-sex institutions, especially female-only schools, and in the northeast.

The relative continuity that we find in the evolution of coeducational schools is in sharp contrast to the implications of the most commonly found reasons offered for its rise. These

\footnotetext{
${ }^{1}$ Newcomer (1959) also employs this definition. Whether or not males and females choose to take the same courses and concentrate in the same subjects, and whether or not they are admitted using the same criteria, are different matters.

${ }^{2}$ The 1934 Coeducation College Database contains 769 institutions that existed at some point from 1897 to 1934 . Of these, 22 closed by 1934 and 59 of the remaining 748 institutions closed after 1934, (others merged but did not officially close). Therefore, only about 8 percent of the institutions existing in 1934 subsequently closed.

${ }^{3}$ The historical literature on coeducation and higher education is sparse. An excellent, but brief, review piece is Rosenberg (1988). See also the essays in Miller-Bernal and Poulson (2004). Several articles contain short summaries of the history of coeducation, including Graham (1978). Early writings on coeducation include Thomas (1900) and Woody (1929). On coeducation at Catholic institutions, see Poulson (1995). A thicker literature exists on women's education. See Newcomer (1959) on women's colleges and Solomon (1985) on women's higher education. Some insightful research exists on individual colleges and universities, including Conable (1977) on Cornell University and McGuigan (1970) on the University of Michigan.
} 
reasons include war, ideological change, and national economic downturns. ${ }^{4}$ Such factors would imply a more episodic evolution of coeducation.

The most recent period of switching in the 1960s and 1970s, during which Dartmouth, Princeton, Yale and a host of elite liberal arts colleges became coeducational, is shown to have increased the fraction of undergraduates in coeducational schools by only a small amount. Although the change opened the doors of many of the best institutions in the nation to women, many others had been opened for a long time.

We offer a framework to understand the switch from single-sex to coeducational status that emphasizes potential tradeoffs between the demand for a coeducational or single-sex environment by current and future undergraduates, on the one hand, and expected alumni contributions by past and future graduates, on the other. Estimates of hazard models of the time to switching from single-sex to coeducational status suggest the role of alumni influence. We find that older and privately-controlled institutions were slower to switch from single sex to coeducation. Linear probability models of institutional switchers with controls for both institutional characteristics and time-varying measures of the competitive environment reinforce our findings on continuity in the rate of switching from the 1870 s to the 1950 s followed by sharp acceleration in the 1960s and 1970s. In a separate analysis we demonstrate that by the 1960s the undergraduate enrollments at institutions that shifted to coeducational status grew faster than those that delayed switching.

Greater access to coeducation in higher education, as we demonstrate, had a positive impact on women's college attainment in the period before the 1930s. Currie and Moretti (2003) present similar findings for the more recent period. Even when women's colleges existed in an area, an increase in coeducational institutions furthered the college education of women relative to men because women's colleges were costly and many coeducational institutions were public and less expensive.

\footnotetext{
${ }^{4}$ On the role of the Civil War in reducing the supply of male students, see Graham (1978, p. 764), Newcomer (1959, p. 12), and Rosenberg (1988); Solomon (1985, p. 188) discusses similar factors with regard to World War II. On war and the changing perceptions of women, see Conable (1977), and on the GI Bill in opening women's colleges to men see Eisenmann (1997), Newcomer (1959), and Solomon (1985). Newcomer (1959) discusses the Great Depression in spurring coeducation among some schools, and Miller-Bernal (2004) claims that both world wars and the Great Depression created financial hardships for small single-sex institutions and prompted them to switch.
} 
The paper is structured as follows. We begin with a brief history of coeducation and then move to a discussion of our coeducation database and a description of the evolution of coeducation. We develop a framework to understand the shift to coeducation by single-sex institutions and then use our data to detect which factors mattered, thereby testing the validity of the framework. The impact of coeducation on female educational attainment is addressed next. We close with a section on the end of in loco parentis, the spread of sex-blind admissions, and the commencement of real gender equality in higher education.

\section{Coeducation Historically Considered}

In 1897, 56 percent of all undergraduates, and 60 percent of undergraduate women, were enrolled in coeducational institutions (Table 1, part A). Coeducation varied considerably by region in 1897, with the Northeast educating just 29 percent of its undergraduates in dual-sex institutions, the South 40 percent, and the Midwest and the West around 86 percent (part B).

Much changed with regard to coeducation in the next quarter century. In 1924 almost three-quarters of all undergraduates were in coeducational settings. Even in the Northeast 52 percent were in coeducational setting and 60 percent were in the South. ${ }^{5}$ By 1980 virtually all undergraduates were educated in coeducational institutions. ${ }^{6}$ The trend for privately controlled institutions closely follows that for all institutions, although private institutions had a lower coeducation share in 1897 than did those in the public sector.

The typical female undergraduate in 1897 went to an institution where 60 percent of the students were female, even though only 29 percent of all undergraduates in four-year institutions were (part C, cols. 1 and 2). In contrast, the typical female college student in 1980 was in a school with only a slightly higher share of women than that faced by the typical male student. A revealing summary statistic is the "isolation index," which measures the degree to which the typical woman is educationally segregated from men with 0 being perfect integration and 1 being complete segregation by sex (that is, only single-sex institutions). In 1897 the isolation index

\footnotetext{
5 "All students" for 1924 include graduate students and those in professional divisions.

${ }^{6}$ Our data differ from those in Newcomer (1959, tables 2, 3). The college data she uses, from the U.S. Office of Education, include two-year institutions whereas ours do not. In consequence she obtains a higher fraction of women in coeducational institutions and a lower fraction in women's colleges.
} 
was 0.44 ; it decreased to 0.30 by around 1930 , and then to 0.05 by 1980 (part C, col. 3 ). ${ }^{7}$

The earliest coeducational institutions in the United States were founded by abolitionists, Congregationalists, Quakers, Methodists, and others committed to equality in general. The institutions were disproportionately founded in the newer parts of the young nation, known at the time as the "West" and included many in Ohio, such as Antioch, Marietta, Oberlin and Wilberforce. Of the 54 institutions that became coeducational before 1860 (and existed in 1934) 27 were in the five states of the Old Northwest (OH, MI, IN, IL, and WI) and another 13 were in states west of the Mississippi. Only one was in New England (Bates College in ME).

The public sector entered the coeducation arena somewhat later than the private sector. Of the 30 public institutions founded before 1860 (and existing in 1934), just three were coeducational at the time of founding or soon thereafter, whereas of the 195 private institutions founded before 1860, 50 (or 26 percent) were coeducational at founding or within a decade of founding. ${ }^{8}$ Part of the slower response of the public sector was because more than half of its 30 institutions founded before 1860 were in the South and southerners had a preference for singlesex education. ${ }^{9}$ But even in the absence of the South the public sector was a coeducational laggard. ${ }^{10}$ Another reason for the greater prevalence of coeducation among private as opposed to public institutions in the ante-bellum era was the religious control of many of the private institutions and the commitment of certain religious denominations to access by all people.

The public sector quickly became more closely associated with coeducation as it moved west. Of the 34 publicly controlled institutions founded from 1861 to 1880, 24 (or 71 percent) were established as coeducational institutions or became so within a decade. In the private sector 122 were founded from 1861 to 1880 and 59 of these (or 48 percent) were coeducational within a

\footnotetext{
${ }^{7}$ The isolation index, it should be noted, takes as given the proportion of students that are female and examines the extent to which female students are institutionally integrated with their male counterparts. ${ }^{8}$ Excluding Catholic institutions, the private sector had 171 institutions founded before 1861 of which 50 (or 29 percent) were coeducational.

${ }^{9}$ In 1861 just 9 percent of private institutions in the South were coeducational, whereas 36 percent were in the rest of the nation.

${ }^{10}$ Non-southern states established 14 public institutions before the Civil War and two were coeducational within five years (Iowa State University and the University of Utah). Another (Michigan State) was coeducational after five years.
} 
decade of founding. ${ }^{11}$

The public higher education sector in the western parts of the nation was coeducational in the nineteenth century for the same reasons that primary and secondary schools in the West were. ${ }^{12}$ These regions were sparsely settled and coeducational facilities were cost-effective.

There was, in addition, a commitment on the part of the public sector to offer training for certain professionals, such as teachers and nurses, and, in much of the nation, to provide equal access. For cash-strapped states, coeducation was cheaper. In 1870, for example, the Michigan state legislature forced the University of Michigan to accept women rather than building a separate institution for them. ${ }^{13}$

Coeducational colleges and universities proliferated in regions that led in the high school movement. In fact, the main reason there could have been a shift to college coeducation in the United States is because of the spread of (coeducational) secondary education across much of the nation in the mid- to late-nineteenth century. ${ }^{14}$ Girls, in fact, went to and graduated from high school in the United States at higher rates than did boys in the late nineteenth century and in every state from the early twentieth century to at least $1940 .{ }^{15}$

The United States was distinctive in the nineteenth century and for much of the twentieth century in terms of the extent of pre-college training for women and its coeducational nature. At the turn of the twentieth century, some Europeans expressed disbelief that Americans educated young women together with young men. The (female) French minister of public instruction remarked in 1893: "Of all the features which characterize American [secondary school] education, perhaps the most striking is the coeducation of young men and young women ... for it reveals a state of mind and of habits which is entirely strange" (Goldin and Katz 2008, p. 154).

\footnotetext{
${ }^{11}$ Excluding Catholic institutions established from 1861 to 1880 , the private sector founded 105 new institutions and 58 of these (or 55 percent) were coeducational within a decade of founding.

${ }^{12}$ All were coeducational at their founding except for mining schools in the Pacific and Mountain states.

${ }^{13}$ See McGuigan (1970) and Rosenberg (1988) on coeducation at the University of Michigan.

${ }^{14}$ This pattern can be seen in the western states but the same factors played out within other states. For example, M. Carey Thomas noted the case of Massachusetts: "It was impossible until 1878 for a Boston girl to be prepared for college in a city high school [because Latin schools in Boston were male-only], whereas, in the country towns of Massachusetts, where boys and girls were taught together ... the girl had had the same opportunities as the boy" (1900, fn. 1, p. 4).

${ }^{15}$ On the high school movement and gender imbalance in secondary schools, see Goldin (1998) and Goldin and Katz (2008).
} 
As more coeducational institutions were established in an area, the prospective founders of new institutions often used the successes of female students in existing coeducational institutions to argue for coeducation. Andrew Dickson White did precisely that to justify coeducation at Cornell in 1872 when he was the inaugural president of that institution. ${ }^{16}$

When male-only institutions were preponderant, as they were in New England and parts of the Middle Atlantic, first mover disadvantage appears to have dominated. ${ }^{17}$ None in a competitive group could move successfully alone, as the case of Wesleyan demonstrates. Wesleyan College (now University) opened in 1831 as a male-only Methodist institution. It became coeducational in 1871 , largely due to Methodist commitment to equality in the wake of the Civil War. In 1909 Wesleyan returned to single-sex status, in part because of the hostile reaction to female undergraduates by male undergraduates and because its closest competitors were elite male-only colleges. Wesleyan became coeducational again in $1969 .^{18}$

Only long after male student demand demonstrably shifted in favor of a coeducational environment did most of the male-only schools in the northeast become coeducational institutions. Our model explains such a lag in the institutional response to shifts in demand as arising from concerns about jeopardizing alumni giving.

\section{The Coeducation College Database}

The Coeducation College Database was formed in two parts. The first part, termed the 1934 Coeducation College Database, contains information for all institutions of higher education

\footnotetext{
${ }^{16}$ Cornell's founders did not consider the issue of coeducation when the institution opened in 1868 . Nothing in the charter of the institution made it male-only. White formed a committee to examine the subject and marshaled evidence on women's successes and achievements from Antioch, Oberlin, and Michigan. White's report and Henry Sage's large donation allowed the institution, in 1872, to become truly coeducational, with a residence for women. Conable (1977) provides an excellent account of the origins of coeducation at Cornell University but also tries to defend the point that coeducation was not equal education at Cornell for a long time to come.

${ }^{17}$ The single-sex status quo dominated because many of the male-only institutions in the northeast were the finest academically in the region. The public sector in the northeast was held back compared with that in the rest of the nation (Goldin and Katz 1999). Deviation from the male-only standard in the northeast was a signal of financial or other weakness. When academic markets widened geographically and when male students preferred to be in coeducational settings, the switch to coeducation became universal.

${ }^{18}$ See Potts (1992).
} 
granting a four-year degree in existence in 1897, 1924, or 1934. The data include time invariant variables such as opening year. Religious affiliation and public versus private control can vary but are generally time invariant. ${ }^{19}$ Other variables are time varying and exist in the data set for the three years given (for example, the number of students enrolled and faculty by program, degrees granted, revenue by source, and expenditure by category). The surveys from which these data were taken were executed by the U.S. Office of Education. The first was published in the 1897 Annual Report of the Commissioner of Education. The other two come from the 192224 and 1932-34 Biennial Surveys of the Commissioner of Education. The 1930s data were supplemented with those from the 1933 College Blue Book.

There are 769 institutions in the 1934 Coeducation College Database, almost all of which were four-year BA granting institutions in 1934 (see Data Appendix). Of the full group, 81 percent were privately controlled and 44 percent were non-sectarian. Catholic was the most common religious affiliation with 16 percent of all institutions (see Table 2).

A critical variable to the investigation here is the year that an institution became coeducational, if it did. We define a coeducational institution as one that has classes for men and women together. These classes must include the central ones in a liberal arts college and cannot be limited to a particular school, such as nursing or education.

Some institutions opened coeducational and others "switched." In the 1934 Coeducation College Database 42 percent of the institutions opened coeducational (39 percent of those in the private sector and 56 percent in the public sector) and 85 percent of the remainder switched at some date to the present. ${ }^{20}$

The moment a single-sex institution switches is generally clear, but classification of some institutions required deeper information. Take Harvard and Radcliffe for example. Harvard opened in 1638; Radcliffe opened in 1882 but never had a faculty of its own. Harvard professors would teach a course in the Harvard Yard and then walk to the Radcliffe Yard and give the course to female undergraduates. When the United States entered World War II, some faculty decided to teach men and women together on an experimental basis and a year later, in 1943,

\footnotetext{
${ }^{19}$ Very few institutions (e.g., Rutgers) changed control over time.

${ }^{20}$ Information on whether the institution opened coeducational or single sex is available for 753 (682 of which remained in operation to the present) of the 769 institutions.
} 
coeducational instruction was accepted. Admissions remained separate until 1976, when genderblind admissions were instituted. Because the definition employed here concerns the sharing of classrooms, the 1943 date is employed. ${ }^{21}$

Institutional data across the three years $(1897,1924$, and 1934) are linked. Mergers that occurred between reporting dates are resolved, but those that occurred before 1897 cannot be considered because institutions that did not survive to 1897 are not in the database. If an institution closed after the 1930s, that date is also recorded. The date at which an institution became coeducational is either the opening date or the date that coeducation was established, gleaned from websites, personal correspondence, and archival information. All institutions that began as single-sex institutions are followed to the present to determine when they became coeducational, if they did. There are 35 female-only colleges still in existence from this group and three male-only colleges.

The second part of the data set, termed the 1980 Coeducation College Database, adds to the group of institutions existing in 1934 all the four-year institutions existing in 1980 that opened after 1934 and contains information on institutional closings and mergers since $1934 .^{22}$ Standard NCES FICE codes and IPEDS UnitID codes are added to the full list of institutions. The database includes 1980 enrollment numbers by sex for all institutions surviving to 1980 .

Thus, the resulting data set contains information on the approximately 1,500 four-year institutions that existed from around 1897 to the present. Enrollment, faculty, and financial data are included for 1897, 1924, and 1934. The year when an institution became coeducational, if it began single sex, is included for all institutions. Precise opening years are available for the 1934 sample but not always for the group that is included after 1934. Some of the institutions added to the 1934 group were previously two-year colleges and the precise year that the school became

\footnotetext{
${ }^{21}$ There are other relevant dates in the coeducation history of Harvard and Radcliffe. Radcliffe women received Harvard degrees in 1963 but the printed degree included the Radcliffe College name until 1977, when an agreement formally put Radcliffe women in Harvard College. Coeducational residential halls are another matter and were formalized at Harvard in 1972. The switch to them is important in the ability of the institution to have gender-blind admissions, as we will later discuss.

${ }^{22}$ Many of the institutions that are added were established before 1934 but as two-year institutions, often teachers' college. We have not been able to obtain the precise date at which each of the added institutions became four-year. In part, this is because of the lack of good institutional memory and also because some of the institutions subsequently failed. But it is also because, in many cases, there were a handful of students who did four-year degrees even when the institution was primarily two-year.
}

Goldin and Katz, Coeducation -8- 
a four-year institution is often difficult to ascertain. ${ }^{23}$

The information on students differs across the various data sets. The 1897 data includes undergraduates in the "collegiate" group and excludes graduate and preparatory students. Independent professional and theological schools in 1897 are omitted from the sample. The 1924 student data includes all students, both undergraduate and graduate, but excludes those in summer school, extension, and military drill courses. The 1934 data separates undergraduates from graduate students and also from those enrolled in a first professional program.

III. Chronology of Coeducation: College Openings and Switchers

In 1934, 64 percent of all four-year institutions with undergraduates were coeducational and 70 percent of undergraduate enrollments were in coeducational institutions. Of the coeducational schools at that time, 34 percent had begun as single-sex institutions.

Coeducation occurs through two routes: the establishment of new coeducational institutions and the conversion of previously single-sex institutions. In the period to 1934, the more important of these two routes was the establishment of public and private institutions that were coeducational from their start. In 1900, for example, 58 percent of schools (that existed in 1934) were coeducational and 73 percent of them had been coeducational from their inception. Similarly, 46 percent of schools were coeducational in 1880 and 72 percent of these were founded as coeducational institutions. ${ }^{24}$

The establishment of male-only schools (in the 1934 Coeducation College Database) from the early 1800 s occurred in a fairly steady manner. Their founding, however, waned after the 1890s (Figure 1, part A). Similarly, the Catholic group of male-only institutions increased continuously to 1890 (Figure 1, part C). The establishment of female-only institutions was somewhat less continuous and did not diminish in the period to 1934. Spurts in the founding of

\footnotetext{
${ }^{23}$ A substantial number of the four-year institutions in the 1980 database that are not present in the 1934 database give opening dates that are before 1934. These institutions were not captured in the Office of Education statistics as four-year schools in 1934. Many of these schools opened as two-year institutions prior to 1934 but actually became four-year institutions between 1934 and 1980 .

${ }^{24}$ Using the 1934 enrollment figures, 65 percent of enrollment was in coeducational institutions in 1900 and 61 percent of the enrollment were in institutions that were coeducational at their opening.
} 
female-only institutions occurred at times, such in the early 1870s and 1890s. A lull in the establishment of women's colleges occurred in the 1860s. Oddly enough, given the Civil War disruption, there was no corresponding pause in the establishment of male-only institutions. The 1910s and 1920s saw the establishment of many new female-only colleges, most of which were Catholic schools (Figure 1, part C). Female-only Catholic schools were almost non-existent before 1900 but exceeded the male-only Catholic schools in number by the mid-1920s.

Prior to 1835 there were no coeducational institutions of higher education in the United States. But that soon began to change. The opening of schools that began as coeducational institutions was fairly continuous starting in 1835, although there was some increase from the mid-1860s to the 1890s (Figure 1, part A). The vast majority of colleges and universities that began as coeducational institutions during the latter part of the nineteenth century were privately controlled, not public state institutions (Figure 1, part B). The importance of the private sector in the growth of coeducation institutions in the late nineteenth century may be surprising given the importance of federal legislation that set up the great state universities that are part of the "land grant" institutions.

The Morrill Act of 1862, which allowed for the establishment of the land grant universities, gave states federal lands they could sell to fund the institutions. ${ }^{25}$ Many of today's flagship state institutions were founded under the Morrill Act. The Morrill Act was a landmark piece of legislation and led to the founding of a large number of public institutions, some of which were coeducational at their establishment. ${ }^{26}$ One might expect, therefore, that the founding of coeducational colleges and universities in the post-1861 period to have been dominated by the public sector.

In terms of the number of institutions, the private sector clearly dominates in the two periods 1861 to 1880 and 1881 to $1900 .^{27}$ The private sector added about 72 percent of the coeducational schools founded in those decades. By enrollment, the public sector is more

\footnotetext{
${ }^{25}$ During the Civil War only the states loyal to the Union received Morrill Act land grants and those in the Confederacy received them when they rejoined the Union after the war.

${ }^{26}$ The 1862 Morrill Act did not require that the institutions founded under its auspices be coeducational and many were not at their outset. The "second Morrill Act" in 1890 concerned the exclusion of blacks from Morrill Act schools in the South and set up many of the historically black colleges and universities. ${ }^{27}$ The fact that the private sector was more important in terms of the number of institutions should not be too surprising since each state generally founded just one land grant institution.
}

Goldin and Katz, Coeducation -10- 
important in the 1861 to 1880 period (with the private sector accounting for about 46 percent of the growth in coeducation using 1897 enrollments and 33 percent using 1934 enrollments). ${ }^{28}$ That finding is to be expected since the public institutions established in those years, such as the Universities of California, Colorado, Kansas, Illinois, Minnesota and Washington, rapidly became behemoths. But the private sector was far more important during the 1881 to 1900 period accounting for 70 percent of the increase in enrollments in coeducational institutions (using 1897 enrollments and 51 percent using 1934 enrollments).

The decadal shift from single-sex (predominantly male-only) to coeducational institutions increased in the years immediately following 1860 but then continued in a somewhat unbroken fashion from the Civil War decade to the 1950s (see Figure 2, part A). About 8 percent of the male-only undergraduate institutions that existed at the start of the decade switched to coeducational status by the end of the decade, for each decade from 1861 to $1950 .{ }^{29}$

The decadal rate of switching was higher in the 1860s than before and a bit higher in the 1870s than just after, which might lend some credence to the notion that the wartime absence of men led to coeducation. ${ }^{30}$ But for the entire group of men's colleges these rates are not much different from those in any of the decades from the 1860s to the 1950s. Of some interest is that the rates during the Great Depression and World War II are not greater than those extending back to the $1860 \mathrm{~s}$, and for the men's non-Catholic group they are considerably smaller (Figure 2, part B). These findings hold up in the hazard and linear probability analyses to be presented.

Catholic institutions (not shown separately) experienced relatively little switching until the 1960s. Many orders founded separate women's colleges in the early to late 1920s to meet the demand for college on the part of women, rather than have their men's colleges become coeducational.

The hazard rate did increase considerably in the 1960s for men's and women's Catholic

\footnotetext{
${ }^{28}$ The reason that the 1897 figure is larger than that using 1934 enrollments concerns the relative growth of the state universities during the first third of the twentieth century.

${ }^{29}$ Throughout this paper, the proportion of single-sex institutions (all or male-only or female-only) existing at the start of a decade that became coeducational during that decade will be referred to as the hazard rate, as in Figure 2.

${ }^{30}$ Institutions that may have folded in the 1860 s cannot be observed, although a search of institutions that closed does not yield a large number for the 1860s. In addition, although some may have folded, the question here is the shift to coeducation.
} 
institutions and for men's non-Catholic colleges (Figure 2, part B). At that point in the history of coeducation a large fraction of the pre-existing men's non-Catholic schools had already become coeducational institutions. In fact, 72 percent of non-Catholic institutions founded as male-only had switched by 1960. Almost all of the remaining male-only schools (both Catholic and nonCatholic schools) switched to coeducational status during the 1960s and $1970 \mathrm{~s} .{ }^{31}$ We discuss this important period and the role of Title IX later.

The growth of coeducational institutions both for the total and the non-Catholic group is shown in Figure 3 by institution (part A) and weighted by 1934 enrollment (part B). In 1860, 25 percent of all institutions (which also existed in 1934) were coeducational (14 percent of the 1934 weighted enrollment). In 1870, 35 percent of the institutions were coeducational (39 percent of the 1934 weighted enrollment) and by 1890 more than half of the institutions were coeducational (more than 60 percent weighted). ${ }^{32}$

Coeducation may have been bolstered by both the Morrill Land Grant Act and the Civil War but the increase in the fraction of coeducational institutions appears relatively constant and substantial from 1861 to the 1910s. The emphasis by some that the Civil War had a strong direct impact on coeducation seems misplaced. The surge in coeducational public institutions, especially in the West, had a greater effect on coeducation than the impact of a dearth in collegeaged men wrought by the war. ${ }^{33}$ Similarly, the emphasis on the role of World War II also seems misplaced since the decades with the lowest rate of switching, before the 1970s, are the 1940s and the 1950s.

A substantial and prominent group of single-sex institutions (including the "big" and "little" Ivies) switched in the late 1960s and early 1970s. Because of the reputation of many in that group, the years from 1967 to 1975 are often accorded a special place in the history of coeducation. The period, however, is far less unique for non-Catholic institutions than for

\footnotetext{
${ }^{31}$ For example, out of the approximately 222 non-Catholic male institutions that opened to 1980, just 38 remained as male-only institutions in 1970 and just 9 survived as all-male colleges to 1980 .

32 The large increase from around 1865 to 1875 in the fraction of the 1934 enrollment in coeducational schools given in Figure 3, part B is due to the establishment of various state universities under the Morrill Land Grant Act, as we noted before. Even if the 1897 enrollment numbers are used, that decade still produces the largest increase in the fraction of undergraduates in coeducational institutions.

${ }^{33}$ On the Morrill Land Grant Act, see Radke-Moss (2008) who emphasizes both the changed ideology after the Civil War and the economic necessity of coeducation in the sparsely-settled West and Midwest.
} 
Catholic ones. Whereas 20 percent of all switching that occurred since 1835 did so from 1967 to 1975 for non-Catholic institutions, 53 percent did for Catholic colleges. ${ }^{34}$ Thus, if the period bears any particular significance it is in the transformation of Catholic institutions of higher education (see Figure 4, part C). When the Catholic institutions are omitted, the increase in coeducation is far less extreme during the 1967 to 1975 era (compare parts A and B).

The change to coeducation among the "big" Ivies (Dartmouth, Princeton, and Yale) and the "little" Ivies, (Amherst, Haverford, Wesleyan, Williams, and other prestigious liberal arts colleges such as Bowdoin, Colgate, Hamilton, Lafayette, and Lehigh) has long been viewed as one of enormous importance. According to many, their switch enabled large numbers of highperforming women to be educated in schools that trained the nation's leaders and whose graduates entered the finest professional and graduate schools. But the admission of women to male-only institutions from 1967 to 1975 increased the percentage of undergraduate women taught in a coeducational environment by only about 4 percentage points. ${ }^{35}$ In fact, the switch from female-only to coeducational institutions during those years had an approximately equal impact on the fraction of women educated with men.

One of the reasons that the opening up of many elite male-only institutions did not have a larger impact is because many of the eastern elite institutions were already coeducational and had been so for some time. Although Dartmouth, Princeton, and Yale admitted undergraduate women for the first time in the period of change, four of the other Ivies - Brown, Cornell, Harvard, and the University of Pennsylvania - were already coeducational. Columbia University would not become fully coeducational until 1983, but the women in its coordinate college, Barnard, could take courses at Columbia. In the rest of the nation, the very best institutions of higher education (e.g., Stanford, University of Chicago, Northwestern, Washington University at St. Louis) began as coeducational schools or became coeducational soon after their founding.

Table 3 gives information on the top 50 schools in the nation according to the 2010 U.S. News and World Report list, when they first opened and when each became coeducational. In the top 50, 23 schools began as coeducational institutions or switched to coed soon after founding and seven others became coeducational before the early twentieth century. In the top

\footnotetext{
${ }^{34}$ These figures include the single-sex institutions that opened after 1934.

${ }^{35}$ Institutions existing in 1966 are included and the 1980 enrollment data are used.
}

Goldin and Katz, Coeducation -13- 
25, 11 were coeducational institutions at founding or soon thereafter and one other (Duke) became coeducational before 1900 .

IV. Theoretical and Empirical Models of Switching from Single Sex to Coeducational

To understand the factors that affect the decision to switch from a single sex to a coeducational institution, we model the decisions of a college that maximizes the present discounted value of its resources. Resources can be thought of as the college's endowment plus the present discounted value of expected future revenue streams (coming from alumni donations, tuition, research grants and public-sector subsidies) net of expected future costs (staffing, equipment, and materials costs), or as a combination of faculty, buildings, other productive resources, savings, and future net revenue streams. In the private sector these resources come mainly from tuition and alumni giving.

Alumni live for a finite number of periods and during their post-college lives give to their institution an amount $g$ per time period which is a positive function of their (intrinsic) ability, $q$. They give the amount $g$ with probability $\lambda_{\mathrm{S}}{ }^{S}$ if the institution remains as they knew it $(\mathrm{S}=$ single sex; superscript refers to the current status of the institution and subscript to its status at the time the individual received a BA) and less, $\lambda_{\mathrm{s}}{ }^{\mathrm{C}}<\lambda_{\mathrm{s}}{ }^{\mathrm{S}}$, if the school switches to being coeducational. We assume that college size does not change, and we consider only the decisions and ability of the representative student from each cohort in every period.

If incoming students remain at a constant ability level, $q$, and the school cannot increase the ability of incoming students by becoming coeducational, the school will be in steady state and has no reason to deviate from its single-sex status. But if future potential students have a reduced demand for attending a single-sex school relative to a coeducational school (from changes in social attitudes increasing the demand for coeducation), then the school will be faced with a tradeoff. $^{36}$ If the institution does not switch, it will be faced with lower quality incoming

\footnotetext{
${ }^{36}$ A related change, reinforcing those from the increased demand of potential incoming students for coeducation, is that current alumni may decrease $\lambda_{\mathrm{s}}^{\mathrm{S}}$ and increase $\lambda_{\mathrm{s}}{ }^{\mathrm{C}}$, if their daughters would benefit from college. Rossi (1987) provides guidance regarding the financial and demographic factors that led schools to remain single sex and those that caused it to embrace coeducation. See also Miller-Bernal (2004) on the enrollment and financial concerns of single-sex college administrators in the late 1960s.
} 
students who will give less as alumni. If the institution becomes coeducational, existing alumni will cut back on their giving (from $\lambda_{\mathrm{s}}{ }^{\mathrm{S}}$ to $\lambda_{\mathrm{s}}{ }^{\mathrm{C}}$ ), but the effect will be largely eroded over time as these individuals die. ${ }^{37}$ In addition, the new alumni and alumnae will give more because of their higher $q$ and the effect will be reinforced if $\lambda_{c}{ }^{C}$ is greater than $\lambda_{\mathrm{s}} \mathrm{S}$.

The institution can remain single sex, appease existing alumni, but get lesser-quality students or it can switch to coeducational status, have reduced giving among prior alumni, but gain better (and possibly more) students. ${ }^{38}$ Intelligent administrators will discount the two streams and choose the optimal switching date when long-term gains from switching just begin to outweigh short-term losses.

One of the model's predictions in the face of secularly rising student demand for coeducation is that current student quality will decline (particularly relative to competing coeducational institutions) before a single-sex school switches, and possibly long before. In addition, after the switch alumni donations will initially decline relative to what they would have been in the absence of the switch to coeducation. Donations will eventually improve as the composition of the alumni shifts towards newer cohorts who attended in the coeducation regime. Nevertheless, under the optimal policy, an institution's president will choose to "bite the bullet" and make the switch before the net financial gains from coeducation become apparent.

The trade-offs suggested by the model are borne out in the histories of single-sex schools. According to Karabel (2005, chap. 14), in 1956 Yale's admissions officer observed that many of their best admits had chosen coeducational institutions and that student quality at Yale was declining. But Yale alumni were strongly resistant. By the mid-1960s current students at Yale were demanding a switch to coeducation. At Princeton 55 percent of alumni polled in 1969 were opposed to coeducation, but the trustees supported the switch to stem declining quality. ${ }^{39}$ Similar changes occurred at the other all-male institutions in the 1960s and 1970s.

\footnotetext{
${ }^{37}$ The larger the group of alumni relative to current students, and the more important their donations relative to tuition, the longer it will take for the change to impact the objective function of maximizing the present discounted value of resources.

${ }^{38}$ The switch to coeducation is assumed in the model to be irrevocable and, in fact, almost all were.

${ }^{39}$ A dissent, filed by director of development Arthur J. Horton '42, noted: "I fear that there will be alumni who, liking the University as an all-male institution, could lose much of their present ardor" and reduce their alumni giving. He asked: "Can we really argue that we are not getting the best applicants when over $46 \%$ of our senior class graduated last June with Honors." The Patterson Committee advocated the switch over member Horton's lone dissent (Horton Dissent 1968).
}

Goldin and Katz, Coeducation -15- 
It should be emphasized that anti-discrimination legislation did not play a quantitatively important role in the switch to coeducation. Title IX of the Education Amendments of 1972 was passed and its implementation written long after most male-only institutions had decided to become coeducational. ${ }^{40}$

There were, to be sure, other reasons for switching, such as institution-specific fiscal shocks, depletion of potential students due to wartime draft and fatalities, and general economic downturns, the effects of which could be smoothed by a sufficiently large endowment. Public institutions often face different constraints than private colleges because pressures exist for public dollars to serve all people. ${ }^{41}$ State legislatures often forced coeducation on an institution to save expenses on building a separate women's college.

We first examine the institutional characteristics associated with faster or slower transitions of single-sex four-year colleges to coeducational institutions. We estimate formal hazard models of the duration spent as a single-sex school for all colleges starting as a single-sex school in our 1934 and 1980 Coeducation College Databases (including all originally single-sex schools present in 1897, 1924, 1934, and/or 1980). The estimation sample consists of 511 schools of which 281 started as men's colleges and 230 started as women's colleges.

Cox proportional hazard models are estimated for the duration of a spell as a single-sex school using a nonparametric (fully flexible) baseline hazard. ${ }^{42}$ The time at risk for becoming a coeducational institution is assumed to begin in 1835, the year that Marietta College opened and a year after Oberlin College began coeducational classes. In 1837 Oberlin was the first to accept female students into a BA-granting program and to switch from a single-sex to a coeducational institution. ${ }^{43}$ Thus, the time at risk begins in 1835 for schools founded before 1835 and at the

\footnotetext{
${ }^{40}$ The switch of most institutions to coeducation also preceded the interpretation of Title IX in Mississippi University for Women v. Hogan, 102 Supreme Court Reporter 3331 (1982), that private single-sex undergraduate institutions can be exempt from the admissions requirements of Title IX but must comply with constitutional equal protection requirements in admissions.

${ }^{41}$ As M. Carey Thomas, then president of Bryn Mawr College, noted around 1900: "public opinion in the United States almost universally demands that universities supported by public taxation should provide for the college education of women" (1900, p. 358b).

${ }^{42}$ The findings are similar to those from standard parametric models such as with a Weibull hazard.

${ }^{43}$ Fletcher claims that in 1834 when the first college classes began at Oberlin "[male] college students shared their classrooms and class instructions with women," and also that "in 1837 four ladies were admitted to the Collegiate Course [at Oberlin] with the men and in 1841 three of them received the A.B.
}

Goldin and Katz, Coeducation -16- 
actual opening date for schools founded in 1835 or after. A "failure event" is a transition to being a coeducational school. Schools remaining single-sex institutions today (three male-only and 35 female-only in our dataset) are treated as censored spells with 2010 as the censoring date; schools that closed as single-sex schools are treated as spells censored at the date of closing. ${ }^{44}$

The basic hazard models for all single-sex schools and men's and women's colleges separately are presented in Table 4. The models include as the covariates time-invariant institutional characteristics, including a continuous measure of the year of opening and indicator variables for private control (versus public), religious affiliation, and region. The year of opening indicates the strength of alumni resistance to a switch. The religious affiliation shows the particular ideology and, in the case of Catholic institutions, the degree to which their decisions are dictated by a higher authority and are, therefore, coordinated. The reported coefficients are hazard ratios. (A coefficient greater than 1 indicates that a variable increases the hazard rate of being coeducational; a coefficient less than 1 implies it shrinks the hazard rate.)

The estimates for all single-sex schools (men's and women's colleges pooled) in col. (1) indicate that women's colleges persisted as single-sex schools far longer than men's colleges (had a significantly lower hazard rate) conditional on region and other school characteristics. All three columns of Table 4 indicate that private institutions were slower than public institutions in becoming coeducational. For the initially all-male schools, the land grant institutions were particularly rapid in making the transition to coeducation, while technology (and military) institutions and historically black colleges persisted longer as all-male institutions. Transitions to coeducational status have been far more rapid for institutions that opened in the more recent period and that finding remains when the sample is limited to institutions founded after 1835 .

Catholic schools and nonsectarian private institutions were slower to become coeducational than were private single-sex schools having other, mainly Protestant, religious affiliations (e.g., Baptist, Lutheran, Methodist) for both men's and women's colleges. Single-sex

degree, the first bona fide college degrees ever granted to women" (1943, pp. 379-80). Marietta College began in 1835 as a coeducational institution but may not have granted a BA degree until later.

${ }^{44}$ We know of only one school, Wesleyan College, that began male only, switched to coeducational status, returned to male only, and late became coeducational (Potts 1992). Colby College began coeducational, created a coordinate women's institution, and later returned to being coeducational (Marriner 1963). The decision to switch to coeducational status, here, is treated as irreversible. 
schools in the Midwest (especially those in the East North Central) were quicker to transition to coeducational status than were those in other parts of the country. Schools in the South (especially the South Atlantic) were the biggest laggards for men's colleges followed by those in New England and the Middle Atlantic. Women's colleges in New England were the slowest to make the transition to coeducational status. ${ }^{45}$

The dynamics of transitions from single-sex to coeducational schools are next examined focusing on the roles of time-varying aggregate factors (such as wars, changes in attitudes, and macroeconomics conditions) captured by decade dummies, and "competition" with or "substitutability" by existing coeducational schools. We estimate linear probability models of the transition from single-sex to coeducational schools with controls for time-invariant institution characteristics, decade dummies, and a time-varying state competition variable (the share of the state enrollment in coeducational schools at the start of the decade). The basic findings of the linear probability models are similar to those from probit and logit models.

The unit of observation is a school-decade with a 0 for the dependent variable indicating that a school remained single sex throughout the decade and a 1 meaning it switched to coeducation during the decade. For example, the observation for a single-sex school at the start of the 1960s would have a 1 for the dependent variable if the school became coed from 1961 to 1970 and a 0 if it remained single sex at the start of the next decade (1970).

The full sample covers the 511 initially single-sex schools in the 1934 and 1980 Coeducation College Databases yielding 3,899 school-decade observations. The regressions include observations for each single-sex school from its opening (or from 1830 if it opened before 1830) to the decade it switched to being coeducational (or to the 2000s if it remained single sex by 2010 or to its decade of closure if it closed as a single-sex school). We cluster the standard errors at the state level to account for the state $\times$ year nature of the coeducation competition variable and repeated observations per institution. ${ }^{46}$

Table 5 presents the core findings of the linear probability duration models for all singlesex schools and for men's colleges and women's colleges separately. We include a full set of

\footnotetext{
${ }^{45}$ Note that although the regressions indicate that the West was slower than the northeast, New England (included in the northeast) was the slowest.

${ }^{46}$ The standard errors are similar if one clusters, instead, by institution.
}

Goldin and Katz, Coeducation -18- 
census division dummies and the same controls for time-invariant school characteristics as in Table 4, as well as the coeducational share of state college enrollment.

The impacts of the time-invariant school characteristics mirror those in Table 4. A lower transition rate to coeducational status is found for women's colleges, private colleges, technical institutes, historically black colleges, Catholic and nonsectarian schools and a faster rate is estimated for land-grant schools. For all single-sex colleges and men's colleges, more competition from coeducational schools in one's state at the beginning of a decade is associated with a slower transition to coeducational status (or greater persistence as a single-sex school) suggesting that "substitutability" across institutions and product differentiation dominated, perhaps until the late 1960s. The result holds when the coeducation competition variable is defined as the share of all students in coeducational schools in the state and when it is the share of public students in coeducational schools in the state. The coeducation competition variable, however, does not have a detectable effect for the women's colleges (Table 5, col. 3).

The decade coefficients show little evidence of large and distinctive impacts of the war and recession periods. For men's colleges, the transition rate increases substantially in the 1860s and 1870 s (relative to the 1830 s to the 1850 s), stays at the new higher levels through the $1950 \mathrm{~s}$, and then jumps in the 1960s and 1970s. That jump is dominated by the large number of switches concentrated from around 1967 to the early 1970s for both elite schools in the northeast and for Catholic men's schools. The time trend for women's colleges shows almost no transition to coeducation until the 1940s and 1950s and a large increase in the 1960s and 1970s.

Prior to the 1960s, institutions that switched from single-sex to coeducational status were an idiosyncratic group, whereas after the 1960s they were mainly in the northeast or Catholic. For institutions outside the northeast and for those that were not under Catholic control, individual institutional factors, rather than aggregate downturns and wartime disruptions, were overriding considerations. The switch was occasionally due to the preference of a college president or a large benefactor. Religious ideology, particularly in the wake of the Civil War, played a role for some. And for others, institutional economic distress was the critical factor. Schools that were commuter institutions, where residential living was unimportant, made the transition seamlessly. 
By 1960 the surviving male-only institutions were clustered in the northeast and were disproportionately Catholic. ${ }^{47}$ In 1890 , at the approximate peak of male-only schools in the Midwest, there were 43 and just 17 remained by 1960. In the South there were 64 at its peak in 1880 and 25 survived to 1960 . But in the northeast, where there were 59 at the peak in 1880, 51 still existed in 1960. Among the non-Catholic male-only institutions in the South there were 58 in 1880 but 16 in 1960, whereas in the northeast 51 existed in 1870 and 36 remained in 1960.

In the cases of the northeast male-only and the Catholic institutions, coordination brought about speedy change and can account for the more rapid conversion in the 1960s and 1970s. The groundwork for both groups was laid in the 1950s.

For the Catholic institutions, the Second Vatican Council (1962 to 1965) pronounced that women had the right "to acquire an education ... equal to [that] recognized for men."48 Catholic colleges, according to trenchant criticisms launched in the mid-1950s, could not aspire to be serious research institutions given the narrowness of their instruction and the limitations of reconciling science with Church teachings. ${ }^{49}$ As male-only institutions began to lose their best men to coeducational institutions, the elite institutions of the northeast switched to coeducation, and Catholic schools soon joined that bandwagon.

The model we propose to understand when institutions would optimally switch from single sex to coeducation emphasized the possibility of declining quality of students after student demand changed in favor of coeducation but before institutions made the switch. Although we cannot measure the quality of the student body for all the institutions in a consistent manner spanning the long historical period covered by our sample, we can examine the quantity of students for the period since 1966. Single-sex institutions at the upper end of the quality distribution probably did not suffer declining numbers when demand shifted in favor of coeducation, but less prestigious institutions may have faced declining enrollments. To examine further the implications of the framework, Table 6 provides estimates of the impact on BA growth of switching or remaining single sex during various periods for institutions that opened

\footnotetext{
${ }^{47}$ Most of the Catholic institutions that switched before the late 1960s were founded by the Jesuits or other Catholic missionaries.

${ }^{48}$ See Poulson (1995, p. 122-3).

${ }^{49}$ See Gleason (2001), in particular his discussion of Msgr. John Tracy Ellis's biting criticism of the scholarship and research records of American Catholic higher education.
}

Goldin and Katz, Coeducation -20- 
all-male or all-female relative to those that opened coeducational. In each case BAs are measured as all BAs, male (or female) BAs, and all BAs restricted to non-Catholic institutions.

To examine whether schools that were slow to switch to coeducation suffered losses in enrollments as the demand for coeducation among undergraduates increased, we estimate the following relationship. We regress the growth in BAs from 1966 to 1974 (thus the growth in entering freshmen from 1962 to 1970) on the year the school first opened, the initial 1966 level (in logs) of BAs, control of institution, region dummies, and whether the school was always coeducational, changed before 1962, or changed from 1962 to 1970 . The omitted category includes institutions that were not coeducational by 1970. The question, therefore, is whether the late-comers - those that became coeducational after 1970 - grew slower than the others.

By measuring the dependent variable as the growth in BAs for all students we may overstate the difference between the early switchers and the others since, in some cases, the trustees' condition for the move to coeducation was that the number of male students never go below the existing level. For a while that was true for Yale as well as for Dartmouth. In these cases, switching from single sex to coeducation increased enrollments by definition. But by restricting the dependent variable to only males or only females we would generally understate the difference by excluding the new group. Therefore, we estimate the equation both ways. The initial three rows of the table give the effect on the growth of BAs of changing early versus late and the other rows show the estimates for the key control variables.

We find that institutions that were always coeducational or changed before 1970 had faster BA growth from 1966 to 1974 than those that changed after 1970, if at all. The one instance where that is less clear is in col. (2) where the coefficient on switching from 1962 to 1970 for male BAs is smaller and less significant than the others. Institutions that initially began as all-female had the largest percentage decrease in enrollment if they remained single sex by 1970 (cols. 4, 5, and 6) and that is true even if one restricts attention to female BAs (col. 5). A single-sex institution of either gender that remained single sex after 1970 had lower enrollment growth (as measured by BAs) by about $25 \log$ points during the eight-year period from 1962 to 1970 than one that switched during those years. 
V. Coeducation and Female Educational Attainment

Currie and Moretti (2003) provide evidence that an increase in the number of colleges that women (born from 1925 to 1975 and turning 25 years old from 1950 to 2000) could attend in a county is associated with greater educational attainment of young women in that area. ${ }^{50}$ The increase in the colleges that women were able to attend by county came about through new college openings and the switch of single-sex male colleges to coeducational schools. Thus coeducational institutions of higher education appear to have mattered to the education of women in the recent past. ${ }^{51}$ But was that also the case as coeducation began to increase in much of the nation in the 1910s and 1920s?

We next explore whether increased access to coeducational institutions played a role in greater female college attainment earlier in the twentieth century. Even if female-only colleges existed, they would not have been as numerous as the full group of institutions and thus would have been less convenient than had coeducation been the norm. And most female-only colleges would not have provided as complete and as high-quality an education as the larger coeducational institutions. These institutions were, in addition, considerably more expensive than coeducational institutions in the private or public sectors during the first half of the twentieth century. ${ }^{52}$

To evaluate the possibility that an increase in coeducational institutions was beneficial to women's education earlier in the twentieth century, we use the eventual educational attainment of a birth cohort, as gleaned from the U.S. population censuses. We aggregate to (birth cohort $x$ state of birth) cells. The fraction of females in a (birth cohort $\times$ state) attending college is then

\footnotetext{
${ }^{50}$ An increase in women's education has been shown to improve the life chances of her offspring, increase the probability that she is married, improve her health, and reduce her fertility. For references see Currie and Moretti (2003) and Oreopolous and Salvanes (2011). Although these considerations are beyond the scope of this paper, these beneficial outcomes to individuals and society suggest why the education of women is important historically and in developing nations today.

${ }^{51}$ Our analysis is at the state-cohort level for women born at the start of the twentieth century. Currie and Moretti (2003) exploit high-frequency county-level data for more recent birth cohorts to see if college openings and switching from male-only to coeducation positively impacted women's college education. ${ }^{52}$ The average annual cost (tuition, fees, and minimum room and board) at female-only institutions in 1934 was $\$ 650$. It was $\$ 549$ at male-only institutions and $\$ 386$ for coeducational institutions ( $\$ 239$ for publics). A female-only college was almost three times as expensive as a state university. The greater expense was mainly because these were costly institutions with lower student/faculty ratios and nicer residential living.
} 
regressed on the fraction of undergraduates in the state who attended a BA-granting coeducational institution of higher education (or the fraction of such institutions in the state) when the cohort was around 25 years old. Undergraduate data for 1934 are used to form the weighted enrollment percentages.

The regressions are estimated two ways: (1) with the female attendance rate as the dependent variable and the male college rate as a separate regressor, and (2) as the ratio of the female to male college attendance rates. ${ }^{53}$ We also add the public high school graduation rate for females in 1920 or the ratio of the same for females to males. The reason for its inclusion is that states with better high schools could also have been those with more coeducational colleges and greater educational attainment more generally. The regressions are weighted by cohort population to reveal the experience of the typical female rather than the typical state. ${ }^{54}$

We focus our empirical work here on the impact that coeducational college access had on women's college going in the period of the 1910s and 1920s when coeducation was becoming the norm yet regional variation remained. The regressions in Table 7 cover the birth cohorts that were about 25 years old in 1920 (and in 1930), the college educations of which are given by individuals who were 50 to 59 years old in the 1950 (and 1960) censuses. In addition, since the enrollment data used to weight coeducational institutions are for 1934, these data would best reflect the experiences of these cohorts.

The regression results are given in Table 7 for cohorts that were about 25 years old in 1920 (born 1891 to 1900) and 1930 (born 1901 to 1910) and for the two ways of expressing the dependent variable. We find that the fraction of females who completed some college (that is attained more than 12 years of education) by the time they were in their fifties, given the same for males (or, instead, the ratio of females to males who attended college), is positively related to the fraction of institutions in the state that were coeducational when the cohort was about 25 years old. Similarly, these two dependent variables are also related to the fraction of individuals who attended coeducational institutions in the state when the cohort was about 25 years old. The

\footnotetext{
${ }^{53}$ We have also estimated the regressions using the female college graduation rate and the corresponding female to male ratio. The relative magnitudes and significances are not much different.

${ }^{54}$ The use of population weights is also sensible to down-weight low-population states in the West that had no single-sex institutions and to give less weight to noisier estimates of state-cohort means derived from smaller samples.
} 
coefficients of interest suggest that a one-standard deviation increase in the fraction of institutions in the state that were coeducational would increase the female to male college attendance rate by around 11 to 15 percent without including the public high school graduation rate and by around 5 to 8 percent including it.

The relationship we estimate mainly reflects differences across regions, as can be seen in the example given by Figure 5. In the states of the northeast, coeducation rates were low and women had college attendance rates that were considerably lower than men's. The South generally had somewhat higher coeducation rates and also higher relative college attendance rates for women. In the Midwest and West, in contrast, the fraction of institutions that were coeducational and the fraction of students in them were exceptionally high. In consequence, women achieved higher levels of college attendance relative to men. The states of the northeast had somewhat higher levels of college education for males, but it was the states of the West that had the highest levels for men and for women as well.

Some states, generally the smaller ones west of the Mississippi, had no single-sex colleges because their populations were so sparse that their primary or only higher education institutions were coeducational and in the public sector. These states form somewhat of a cloud in terms of the relationship between coeducation and women's college rates. Because they are small states, the population-weighting procedure reduces their impact in the Table 7 regressions.

VI. Coda: The End of In Loco Parentis and the Beginnings of True Coeducational Equality

By the 1970s the vast majority of female and male undergraduates were educated in coeducational institutions. The fraction female among all undergraduates was rising and would hit the equality mark around 1980. Gender differences in college majors had begun to narrow. But what about the selection of women into institutions that were once male-only? Higher educational institutions that today admit students in a non-discriminatory fashion, with regard to sex, disability, and need, did not always select students in a gender-blind fashion. ${ }^{55}$

\footnotetext{
${ }^{55}$ Interestingly, there are examples of institutions that once became gender-blind but have recently given preference to male applicants to even out the sex distribution.
} 
Many institutions that were once male-only gave preference to men in admissions when they initially became coeducational. In some cases (e.g., Dartmouth, Yale) the preference was due to mandates that were set down by the trustees as a condition for the admission of women (Karabel 2005). But in other cases the preference was partly due to dormitory limitations for women at residential institutions. Some of these institutions had coordinate women's colleges or related institutions (e.g., Radcliffe and Harvard) that had been kept small. In other cases, the fraction female among students was kept down by other factors (e.g., Cornell University and Stanford University) including the lumpiness and fixed costs of building residential halls.

But if men and women could occupy the same residential areas, admissions in many institutions could be gender-blind. That began to happen in the late 1960s with the end of in loco parentis regulations in many colleges and universities.

The end of in loco parentis regulations meant that women no longer had curfews. With no restrictions on hours, universities no longer had to monitor them in dormitories and students could live off campus. In institutions with required residential living, male and female students could occupy the same dormitories and even share the same bathrooms. ${ }^{56}$ The end of residential restrictions on some campuses meant that admissions could be gender-blind. ${ }^{57}$

VII. Summary and Conclusions

Colleges in America accepted women into coeducational settings beginning around 1835. Institutions that were established as coeducational colleges increased in an almost unbroken pace from that time to the present. In a similar fashion, institutions that were founded as male-only switched to coeducational status in a fairly continuous manner with the conversion of Oberlin in 1837 until the $1960 \mathrm{~s}$, when the rate of switching greatly increased.

\footnotetext{
${ }^{56}$ Goldin conducted a small survey of residential colleges and universities. The responses reveal that most lifted hours restrictions from upper-class women from 1966 to 1968, shifted to no hours for all women from 1968 to 1970, and introduced coeducational dormitories beginning around 1969, although some were earlier. Collecting information on residential living arrangements was difficult because of a lack of institutional memory regarding mundane student issues.

${ }^{57}$ At Harvard, for example, "houses" were coeducational on an experimental basis in 1971 and thereafter formally. The admission of men and women became gender-blind and was done by the same committee around 1975. Prior to 1975 the relative number of women to men was increased but was admissions were not gender-blind.
} 
We have sought the reasons for the switch from male-only or female-only to coeducational status for institutions offering four-year undergraduate degrees. Many of the aggregate factors that have been regarded as potentially important do not appear to have mattered greatly for the precise timing of institutional switching. Neither war nor aggregate economic factors accelerated the rate of change for the total group. Time invariant aspects of the institution, such as the type of control, the religious group that founded it, and the opening year of the institution, were important in determining when each of the originally single-sex institutions became coeducational.

The general continuity of change before the 1960s appears due to the fact that institutions were affected by a host of idiosyncratic factors striking them in different years. The same appears to have been the case for the founding of coeducational institutions.

We have also examined whether the increase in institutions that accepted women and taught them in coeducational classes mattered to their educational attainment. Evidence for the more recent period from Currie and Moretti (2003) indicates that increasing the number of institutions that admit women increases the schooling of women in the geographic area. Our analysis of data for the 1910s and 1920s supports the notion that greater accessibility of coeducational college opportunities in a state increased women's college enrollments and, thus, their eventual educational attainment.

Schools founded earlier, thus having larger alumni support, switched later. The demand for coeducation by students increased, probably beginning in the 1950s, and by the 1960s the only force holding coeducation in check was alumni (and alumnae) support for retaining the prior gender identity of the school. For the celebrated period of change in the late 1960s and early 1970s, institutions that switched early or were always coeducational increased enrollments faster than those that switched later, if at all. Declining quality of male students at the top elite institutions in the 1960s led to an almost complete collapse of the single-sex system.

The changes that occurred beginning in the late 1960s were important but focusing on them exclusively omits the long history of coeducation in the United States. Coeducation mattered to women's education throughout U.S. history and it mattered to a greater extent in the more distant past than in the more recent and celebrated period of change. 
Table 1: Students in Coeducational Institutions: 1897, 1924, 1934, 1966, and 1980

A. By Sex

\begin{tabular}{|c|c|c|c|c|c|c|c|c|}
\hline \multirow[b]{2}{*}{ Year } & \multicolumn{2}{|c|}{ All Students } & \multicolumn{2}{|c|}{ Male Students } & \multicolumn{2}{|c|}{ Female Students } & \multicolumn{2}{|c|}{ All Students, Private } \\
\hline & $\begin{array}{c}\text { Fraction } \\
\text { Coed } \\
\end{array}$ & $\begin{array}{l}\text { Number } \\
\text { of Instit. }\end{array}$ & $\begin{array}{c}\text { Fraction } \\
\text { Coed } \\
\end{array}$ & $\begin{array}{l}\text { Number } \\
\text { of Instit. }\end{array}$ & $\begin{array}{c}\text { Fraction } \\
\text { Coed } \\
\end{array}$ & $\begin{array}{l}\text { Number } \\
\text { of Instit. }\end{array}$ & $\begin{array}{c}\text { Fraction } \\
\text { Coed }\end{array}$ & $\begin{array}{l}\text { Number } \\
\text { of Instit. }\end{array}$ \\
\hline 1897 & 0.557 & 432 & 0.538 & 384 & 0.603 & 303 & 0.443 & 343 \\
\hline 1924 & 0.741 & 633 & 0.743 & 516 & 0.738 & 528 & 0.682 & 522 \\
\hline 1934UPG & 0.728 & 692 & n.a. & n.a. & n.a. & n.a. & 0.665 & 554 \\
\hline $1934 U$ & 0.695 & 666 & 0.702 & 530 & 0.686 & 577 & 0.633 & 540 \\
\hline 1934UP & 0.730 & 698 & 0.726 & 561 & 0.736 & 603 & 0.656 & 559 \\
\hline 1966 & 0.934 & 1,165 & 0.947 & 1,134 & 0.921 & 1,157 & 0.825 & 791 \\
\hline 1980 & 0.984 & 1,403 & 0.996 & 1,370 & 0.972 & 1,394 & 0.957 & 913 \\
\hline
\end{tabular}

\section{B. By Region}

\begin{tabular}{|c|c|c|c|c|c|c|c|c|}
\hline \multirow[b]{3}{*}{ Year } & \multicolumn{8}{|c|}{ All Students } \\
\hline & \multicolumn{2}{|c|}{ Northeast } & \multicolumn{2}{|c|}{ South } & \multicolumn{2}{|c|}{ Midwest } & \multicolumn{2}{|c|}{ West } \\
\hline & Fraction & Number & Fraction & Number & Fraction & Number & Fraction & Number \\
\hline 1897 & 0.287 & 95 & 0.397 & 148 & 0.869 & 148 & 0.852 & 41 \\
\hline 1924 & 0.520 & 142 & 0.598 & 213 & 0.941 & 216 & 0.958 & 59 \\
\hline 1934UPG & 0.475 & 155 & 0.713 & 237 & 0.930 & 223 & 0.939 & 74 \\
\hline $1934 U$ & 0.378 & 143 & 0.713 & 234 & 0.884 & 218 & 0.921 & 68 \\
\hline 1934UP & 0.463 & 158 & 0.708 & 238 & 0.921 & 226 & 0.938 & 73 \\
\hline 1966 & 0.838 & 296 & 0.956 & 384 & 0.953 & 334 & 0.984 & 146 \\
\hline 1980 & 0.969 & 354 & 0.984 & 470 & 0.990 & 396 & 0.997 & 172 \\
\hline
\end{tabular}

C. Fraction Female and "Isolation Index"

\begin{tabular}{|c|c|c|c|}
\hline \multirow[b]{2}{*}{ Year } & (1) & (2) & (3) \\
\hline & Fraction Female $(f)$ & "Isolation" (I) ${ }^{\mathrm{a}}$ & "Isolation Index" \\
\hline 1897 & 0.291 & 0.604 & 0.442 \\
\hline 1924 & 0.373 & 0.548 & 0.279 \\
\hline $1934 U$ & 0.439 & 0.626 & 0.333 \\
\hline 1934UP & 0.373 & 0.543 & 0.271 \\
\hline 1980 & 0.499 & 0.524 & 0.0499 \\
\hline
\end{tabular}

a "Isolation" $=\Sigma_{i}\left(\mathrm{~F}_{i} / \mathrm{F}\right) \times\left(\mathrm{F}_{i} / \mathrm{T}_{i}\right)$, where $i$ denotes each institution, $\mathrm{F}_{i}$ is female enrollment in $i, \mathrm{~T}_{i}=$ male plus female enrollment in $i$, and $\mathrm{F}$ is total female enrollment across all institutions. See also Notes (below).

b "Isolation index" $=[(\mathrm{I}-f) /(1-f)]$, where $f=$ col. (1) and I = col. (2). See also Notes (below). 
Sources: See Appendix.

Notes: The definition of "student" changes somewhat across the years. In 1897 the students are in the "collegiate" group and do not include those in professional and graduate programs. In 1924 all students (undergraduates, graduates, and those in professional programs), except those in preparatory and summer school programs are included. The 1934 data allow various combinations for comparison. 1934U includes only Arts and Sciences undergraduates; 1934UP adds undergraduates in first professional degree programs, which were mainly in engineering. 1934UPG includes all undergraduates (plus those in first professional programs) and graduates. The 1934UPG line is most comparable to 1924. The 1934U line is most comparable to 1897 and the 1934UP line is probably most comparable to 1966 and 1980. Undergraduate enrollment data for 1980 are used for the 1966 and 1980 coeducation figures. Institutions are categorized in 1966 on the basis of 1966 enrollment data.

The "isolation index" gives the degree to which a typical female student is "isolated" from male students. "Isolation," termed I, gives the share female of the students in one's own institution experienced by the typical female student. It is computed as the average across institutions of the fraction female among the students in the institution $\left(\mathrm{F}_{i} / \mathrm{T}_{i}\right)$ weighted by each institution's female students as a share of the aggregate number of female students in all institutions $\left(\mathrm{F}_{i} / \mathrm{F}\right)$, where $i$ denotes each institution, $\mathrm{F}_{i}$ is female enrollment in $i, \mathrm{~T}_{i}=$ male and female enrollment in $i$, and $\mathrm{F}$ is total female enrollment across all institutions. If $f=$ the fraction female for all college students in year $t$, the "isolation index" is given by $[(I-f) /(1-f)]$. If all women were in singlesex institutions, the "isolation index" would be 1 . If all women and all men were in coeducational institutions that replicated the aggregate share of female students $(f)$, "isolation" would be the fraction female among all students $(f)$, and the "isolation index" would be 0 .

n.a. $=$ not available 
Table 2: Coeducation College Database Sample Statistics

\begin{tabular}{|c|c|c|c|c|}
\hline Sample statistics for 1934 Coeducation Database & $\begin{array}{l}\text { Number of } \\
\text { Institutions }\end{array}$ & $\begin{array}{l}\text { Fraction of } \\
\text { Institutions }\end{array}$ & Enrollment & $\begin{array}{l}\text { Fraction of } \\
\text { Enrollment }\end{array}$ \\
\hline Total in sample ${ }^{a}$ & 769 & 1.000 & - & - \\
\hline Institutions in sample with 1934 data & 714 & 0.928 & 717,416 & 1.000 \\
\hline Institutions with 1924 or 1897 data only & 55 & 0.072 & - & - \\
\hline Institutions expiring between 1924 and 1934 & 17 & 0.022 & - & - \\
\hline Institutions expiring after 1934 & 53 & 0.069 & 13,541 & 0.019 \\
\hline \multicolumn{5}{|l|}{ Religious affiliation } \\
\hline Non-sectarian & 335 & 0.436 & 499,733 & 0.697 \\
\hline Total with religious affiliation & 434 & 0.564 & 217,683 & 0.303 \\
\hline Catholic & 124 & 0.161 & 69,832 & 0.097 \\
\hline Methodist & 77 & 0.100 & 48,718 & 0.068 \\
\hline \multicolumn{5}{|l|}{ Control } \\
\hline Public & 147 & 0.191 & 316,812 & 0.442 \\
\hline Private & 622 & 0.809 & 400,604 & 0.558 \\
\hline \multicolumn{5}{|l|}{ Gender mix } \\
\hline Founded as all male & 267 & 0.355 & 346,720 & 0.483 \\
\hline Founded as all female & 167 & 0.222 & 63,339 & 0.088 \\
\hline Founded as coeducational & 319 & 0.424 & 302,337 & 0.421 \\
\hline \multicolumn{5}{|l|}{ Regions ${ }^{b}$} \\
\hline Northeast & 166 & 0.216 & 222,847 & 0.311 \\
\hline South & 269 & 0.350 & 171,571 & 0.239 \\
\hline Midwest & 254 & 0.330 & 234,867 & 0.327 \\
\hline West & 77 & 0.100 & 84,756 & 0.118 \\
\hline Sample statistics for 1980 Coeducation Database & $\begin{array}{l}\text { Number of } \\
\text { Institutions }\end{array}$ & $\begin{array}{l}\text { Fraction of } \\
\text { Institutions }\end{array}$ & Enrollment & $\begin{array}{l}\text { Fraction of } \\
\text { Enrollment }\end{array}$ \\
\hline Total in 1980 Database & 1,486 & 1.000 & - & - \\
\hline Total in sample with 1980 data & 1,412 & 0.950 & $5,485,617$ & 1.000 \\
\hline Institutions opening after 1934 & 717 & 0.483 & $2,546,324$ & 0.464 \\
\hline Institutions expiring before $1980^{c}$ & 64 & 0.043 & - & - \\
\hline \multicolumn{5}{|l|}{ Control } \\
\hline Public control & 491 & 0.330 & $3,656,922$ & 0.667 \\
\hline Private control & 921 & 0.620 & $1,828,695$ & 0.333 \\
\hline \multicolumn{5}{|l|}{ Gender mix in $1980^{\mathrm{d}}$} \\
\hline All male & 7 & 0.005 & 8,105 & 0.001 \\
\hline All female & 78 & 0.052 & 78,274 & 0.014 \\
\hline Coeducational & 1,327 & 0.893 & $5,399,238$ & 0.984 \\
\hline \multicolumn{5}{|l|}{ Regions $^{\mathrm{b}}$} \\
\hline Northeast & 356 & 0.240 & $1,289,810$ & 0.235 \\
\hline South & 474 & 0.319 & $1,725,579$ & 0.315 \\
\hline Midwest & 397 & 0.267 & $1,538,805$ & 0.281 \\
\hline West & 174 & 0.117 & 903,033 & 0.165 \\
\hline
\end{tabular}

Goldin and Katz, Coeducation -29- 
a Includes 10 female "coordinate" institutions of male-only colleges.

${ }^{\mathrm{b}}$ Regions do not sum to full sample because AK, HI, PR, and VI are not included in the regional breakdowns.

${ }^{\mathrm{c}}$ Institutions are missing 1980 data either because they closed or were not in the 1980 IPEDS.

${ }^{\mathrm{d}}$ Two institutions are missing coeducational status in 1980.

Sources: See Data Appendix.

Notes: Some columns may not add up to the total because of missing information regarding coeducational or single-sex founding. In the 1980 Coeducation College Database a few institutions appear twice because they represent a merger of two schools from the 1934 data. Undergraduate enrollment in 1934 is used in the upper panel and undergraduate enrollment in 1980 is used in the lower panel. 
Table 3: Top 50 Institutions in U.S. News and World Report 2010 College Rankings

\begin{tabular}{|c|c|c|c|c|c|}
\hline State & City & College name & $\begin{array}{l}\text { Year } \\
\text { Open }\end{array}$ & $\begin{array}{l}\text { Year } \\
\text { Coed }\end{array}$ & $\begin{array}{c}\text { USNWR } \\
\text { Rank } 2010\end{array}$ \\
\hline MA & Cambridge & Harvard University & 1638 & 1943 & 1 \\
\hline NJ & Princeton & Princeton University & 1747 & 1969 & 1 \\
\hline $\mathrm{CT}$ & New Haven & Yale University & 1702 & 1969 & 3 \\
\hline $\mathrm{CA}$ & Pasadena & CA Institute of Technology & 1891 & 1953 & 4 \\
\hline MA & Cambridge & MA Institute of Technology & 1865 & 1870 & 4 \\
\hline $\mathrm{CA}$ & Stanford & Stanford University & 1891 & 1891 & 4 \\
\hline PA & Philadelphia & University of PA & 1755 & 1914 & 4 \\
\hline NY & New York & Columbia University & 1754 & 1983 & 8 \\
\hline IL & Chicago & University of Chicago & 1892 & 1892 & 8 \\
\hline $\mathrm{NC}$ & Durham & Duke University & 1838 & 1894 & 10 \\
\hline $\mathrm{NH}$ & Hanover & Dartmouth College & 1770 & 1972 & 11 \\
\hline IL & Evanston & Northwestern University & 1855 & 1869 & 12 \\
\hline MO & Saint Louis & Washington University & 1854 & 1869 & 12 \\
\hline MD & Baltimore & Johns Hopkins University & 1876 & 1972 & 14 \\
\hline NY & Ithaca & Cornell University & 1868 & 1870 & 15 \\
\hline RI & Providence & Brown University & 1765 & 1971 & 16 \\
\hline GA & Atlanta & Emory University & 1837 & 1953 & 17 \\
\hline $\mathrm{TX}$ & Houston & Rice Institute & 1912 & 1912 & 17 \\
\hline $\mathrm{TN}$ & Nashville & Vanderbilt University & 1875 & 1875 & 17 \\
\hline $\mathrm{IN}$ & Notre Dame & University of Notre Dame & 1843 & 1972 & 20 \\
\hline CA & Berkeley & University of CA & 1869 & 1869 & 21 \\
\hline $\mathrm{PA}$ & Pittsburgh & Carnegie-Mellon University & 1905 & 1905 & 22 \\
\hline $\mathrm{DC}$ & $\mathrm{DC}$ & Georgetown University & 1812 & 1969 & 23 \\
\hline CA & Los Angeles & University of CA, LA & 1919 & 1919 & 24 \\
\hline VA & Charlottesville & University of VA & 1825 & 1970 & 24 \\
\hline CA & LA & University of Southern CA & 1880 & 1880 & 26 \\
\hline MI & Ann Arbor & University of MI & 1841 & 1870 & 27 \\
\hline MA & Medford & Tufts University & 1855 & 1892 & 28 \\
\hline $\mathrm{NC}$ & Chapel Hill & University of $\mathrm{NC}$ & 1795 & 1897 & 28 \\
\hline $\mathrm{NC}$ & Wake Forest & Wake Forest University & 1834 & 1942 & 28 \\
\hline MA & Waltham & Brandeis University & 1948 & 1948 & 31 \\
\hline NY & New York & New York University & 1832 & 1873 & 32 \\
\hline VA & Williamsburg & College of William \& Mary & 1693 & 1918 & 33 \\
\hline MA & Chestnut Hill & Boston College & 1863 & 1970 & 34 \\
\hline GA & Atlanta & GA School of Technology & 1888 & 1952 & 35 \\
\hline PA & Bethlehem & Lehigh University & 1866 & 1971 & 35 \\
\hline CA & La Jolla & University of CA, San Diego & 1960 & 1960 & 35 \\
\hline NY & Rochester & University of Rochester & 1850 & 1900 & 35 \\
\hline IL & Urbana & University of IL & 1868 & 1868 & 39 \\
\hline
\end{tabular}

Goldin and Katz, Coeducation -31- 


\begin{tabular}{|llllll|} 
WI & Madison & University of WI & 1849 & 1863 & 39 \\
OH & Cleveland & Case-Western University & 1880 & 1960 & 41 \\
NY & Troy & RPI & 1824 & 1942 & 42 \\
CA & Davis & University of CA, Davis & 1905 & 1905 & 42 \\
CA & Santa Barbara & University of CA, SB & 1909 & 1909 & 42 \\
WA & Seattle & University of WA & 1861 & 1861 & 42 \\
CA & Irvine & University of CA, Irvine & 1965 & 1965 & 46 \\
PA & State College & PA State University & 1859 & 1871 & 47 \\
FL & Gainesville & University of FL & 1853 & 1947 & 47 \\
TX & Austin & University of TX & 1883 & 1883 & 47 \\
LA & New Orleans & Tulane University & 1835 & 1886 & 50 \\
FL & Miami & University of Miami & 1926 & 1926 & 50 \\
\hline \hline
\end{tabular}

Source: http://colleges.usnews.rankingsandreviews.com/best-colleges/national-universitiesrankings 
Table 4: Cox Proportional Hazard Models of the Transition from Single Sex to Coeducational

\begin{tabular}{|lccc|}
\hline \hline & $(1)$ & $(2)$ & $(3)$ \\
& All Colleges & Men's Colleges & Women's Colleges \\
\hline Women's college & 0.267 & - & - \\
Private control & $(0.0339)$ & & 0.531 \\
Year of opening & 0.454 & 0.534 & $(0.186)$ \\
& $(0.0965)$ & $(0.144)$ & 1.05 \\
Catholic & 1.03 & 1.02 & $(0.00503)$ \\
& $(0.00203)$ & $(0.00225)$ & 0.639 \\
Nonsectarian & 0.453 & 0.333 & $(0.181)$ \\
& $(0.0664)$ & $(0.0631)$ & 0.647 \\
Land Grant institution & 0.592 & 0.548 & $(0.182)$ \\
Technology or military institute & $(0.0859)$ & $(0.979)$ & - \\
Historically black college & 2.78 & 3.01 & - \\
South & $(0.670)$ & $(0.814)$ & \\
Midwest & 0.372 & 0.416 & $(0.0982)$ \\
West & $(0.081)$ & 0.660 & $(0.158)$ \\
Number of observations & 0.499 & $(0.252)$ & 1.21 \\
\hline
\end{tabular}

Sources and Notes: The sample includes all four-year institutions starting as single-sex institutions in our 1934 and 1980 Coeducation College Databases. In other words, the sample consists of all originally single-sex schools present in our 1897, 1924, 1934, or 1980 institutional samples. The estimation uses Cox proportional hazard models for the duration of a spell as a single-sex school with nonparametric baseline hazards estimated via maximum likelihood using the "stcox" command in STATA. The time period at risk in the duration models begins in the year of opening for institutions founded after 1835 and in 1835 for institutions that opened before 1835. The failure event is the transition to a coeducational institution. Schools that continue today as single-sex institutions are treated as censored spells with 2010 as the date of censoring. Schools that closed as single-sex institutions are treated as censored at the date of closing. The reported coefficients are hazard ratios. The standard errors for the hazard ratios are in parentheses. The base region is the northeast (New England plus the Middle Atlantic states). There are no land grant and no technical institutions among the women's colleges. 
Table 5: Linear Probability Models of Decadal Transitions from Single-Sex to Coeducational

\begin{tabular}{|c|c|c|c|}
\hline & $\begin{array}{c}(1) \\
\text { All Colleges }\end{array}$ & $\begin{array}{c}(2) \\
\text { Men's Colleges }\end{array}$ & $\begin{array}{c}(3) \\
\text { Women's Colleges }\end{array}$ \\
\hline $\begin{array}{l}\text { Coeducational share of state } \\
\text { enrollment }\end{array}$ & $\begin{array}{c}-0.0567 \\
(0.02633)\end{array}$ & $\begin{array}{l}-0.0807 \\
(0.0327)\end{array}$ & $\begin{array}{l}-0.0231 \\
(0.0257)\end{array}$ \\
\hline Women's college & $\begin{array}{c}-0.115 \\
(0.0961)\end{array}$ & - & - \\
\hline Private control & $\begin{array}{l}-0.0658 \\
(0.0165)\end{array}$ & $\begin{array}{l}-0.0744 \\
(0.0300)\end{array}$ & $\begin{array}{l}-0.0423 \\
(0.0263)\end{array}$ \\
\hline Year of opening $\times 10^{-2}$ & $\begin{array}{c}0.0394 \\
(0.0114)\end{array}$ & $\begin{array}{c}0.0287 \\
(0.0130)\end{array}$ & $\begin{array}{c}0.0715 \\
(0.0261)\end{array}$ \\
\hline Catholic & $\begin{array}{l}-0.0785 \\
(0.0142)\end{array}$ & $\begin{array}{c}-0.121 \\
(0.0176)\end{array}$ & $\begin{array}{l}-0.0236 \\
(0.0193)\end{array}$ \\
\hline Nonsectarian & $\begin{array}{l}-0.0562 \\
(0.0133)\end{array}$ & $\begin{array}{l}-0.0755 \\
(0.0202)\end{array}$ & $\begin{array}{l}-0.0219 \\
(0.0141)\end{array}$ \\
\hline Land Grant institution & $\begin{array}{c}0.0994 \\
(0.0301)\end{array}$ & $\begin{array}{c}0.108 \\
(0.0376))\end{array}$ & - \\
\hline Technology or military institute & $\begin{array}{l}-0.0555 \\
(0.0178)\end{array}$ & $\begin{array}{l}-0.0662 \\
(0.0248)\end{array}$ & - \\
\hline Historically black college & $\begin{array}{l}-0.0522 \\
(0.0479)\end{array}$ & $\begin{array}{l}-0.0364 \\
(0.565)\end{array}$ & $\begin{array}{l}-0.0742 \\
(0.0485)\end{array}$ \\
\hline \multicolumn{4}{|l|}{ Decade dummies } \\
\hline $1850 \mathrm{~s}$ & $\begin{array}{c}0.0130 \\
(0.00860)\end{array}$ & $\begin{array}{c}0.00554 \\
(0.00987)\end{array}$ & - \\
\hline $1860 \mathrm{~s}$ & $\begin{array}{c}0.0745 \\
(0.0253)\end{array}$ & $\begin{array}{c}0.0743 \\
(0.0307)\end{array}$ & - \\
\hline $1870 \mathrm{~s}$ & $\begin{array}{c}0.0931 \\
(0.0171)\end{array}$ & $\begin{array}{c}0.105 \\
(0.219)\end{array}$ & - \\
\hline $1880 \mathrm{~s}$ & $\begin{array}{c}0.0896 \\
(0.0240)\end{array}$ & $\begin{array}{c}0.104 \\
(0.319)\end{array}$ & - \\
\hline $1890 \mathrm{~s}$ & $\begin{array}{c}0.110 \\
(0.0220)\end{array}$ & $\begin{array}{c}0.123 \\
(0.0274)\end{array}$ & - \\
\hline $1900 \mathrm{~s}$ & $\begin{array}{c}0.115 \\
(0.0240)\end{array}$ & $\begin{array}{c}0.142 \\
(0.341)\end{array}$ & - \\
\hline $1910 \mathrm{~s}$ & $\begin{array}{c}0.136 \\
(0.0289)\end{array}$ & $\begin{array}{c}0.169 \\
(0.0447)\end{array}$ & $\begin{array}{c}0.00322 \\
(0.00984)\end{array}$ \\
\hline $1920 \mathrm{~s}$ & $\begin{array}{c}0.124 \\
(0.0247)\end{array}$ & $\begin{array}{c}0.132 \\
(0.347)\end{array}$ & $\begin{array}{l}0.00788 \\
(0.0127)\end{array}$ \\
\hline $1930 \mathrm{~s}$ & $\begin{array}{c}0.145 \\
(0.0246)\end{array}$ & $\begin{array}{c}0.169 \\
(0.0398)\end{array}$ & $\begin{array}{c}0.0145 \\
(0.0142)\end{array}$ \\
\hline $1940 \mathrm{~s}$ & $\begin{array}{c}0.161 \\
(0.0332)\end{array}$ & $\begin{array}{c}0.170 \\
(0.0392)\end{array}$ & $\begin{array}{l}0.0377 \\
(0.212)\end{array}$ \\
\hline
\end{tabular}

Goldin and Katz, Coeducation -34- 


\begin{tabular}{|cccc|}
\hline $1950 \mathrm{~s}$ & 0.174 & 0.176 & 0.0523 \\
& $(0.0304)$ & $(0.417)$ & $(0.0247)$ \\
$1960 \mathrm{~s}$ & 0.504 & 0.613 & 0.319 \\
& $(.0427)$ & $(0.0682)$ & $(.0514)$ \\
$1970 \mathrm{~s}$ & 0.446 & 0.650 & 0.225 \\
$1980 \mathrm{~s}$ & $(0.0458)$ & $(0.817)$ & $(0.0416)$ \\
& 0.328 & 0.408 & 0.177 \\
$1990 \mathrm{~s}$ & $(0.0439)$ & $(0.120)$ & $(0.0348)$ \\
& 0.229 & 0.599 & 0.0438 \\
$2000 \mathrm{~s}$ & $(0.0489)$ & $(0.128)$ & $(0.0437)$ \\
& 0.403 & 0.0749 & 0.279 \\
Census division dummies & $(0.0713)$ & $(0.0518)$ & $(0.0679)$ \\
Number of observations & Yes & Yes & Yes \\
Number of institutions & 3,899 & 2,097 & 1,802 \\
\hline \hline
\end{tabular}

Sources and Notes: The unit of observation is school $\times$ decade. All single-sex schools in the 1934 and 1980 Coeducation College Databases are included covering schools present in our $1897,1924,1934$, or 1980 institutional samples. The base period is the 1830 s and 1840 s for columns (1) and (2) and it is the 1830s to the 1900s for column (3). The dependent variable is a 1 if the school switched to coeducational during that decade (e.g., for a school that was single sex in 1960 a 1 for the dependent variable for the 1960s means it became coed from 1961 to 1970 and a 0 means it remained single sex at the end of the decade or closed during the decade). Schools leave the sample starting in the decade after they become coeducational. Standard errors are clustered by state. The variable "Coeducational share of state enrollment" is a time-varying covariate that varies by state and decade. It measures the share of enrollment in coeducational schools in the institution's state at the start of the decade. We use 1934 enrollments for the 1830 s to 1930 s period and 1980 enrollments for the 1940s to 2000s. There are no land grant and no technical institutions among the women's colleges. 
Table 6: Impact on BA Growth of Switching from Single Sex to Coeducational, 1966 to 1974

\begin{tabular}{|c|c|c|c|c|c|c|}
\hline \multirow[b]{2}{*}{$\begin{array}{l}\text { Growth in BAs from } \\
1966 \text { to } 1974 \text { (Freshmen } \\
\text { from } 1962 \text { to } 1970 \text { ) }\end{array}$} & \multicolumn{3}{|c|}{ Initially All Male or Coeducational } & \multicolumn{3}{|c|}{ Initially All Female or Coeducational } \\
\hline & $\begin{array}{c}(1) \\
\text { All BAs }\end{array}$ & $\begin{array}{c}(2) \\
\text { Male BAs }\end{array}$ & $\begin{array}{c}(3) \\
\text { All BAs } \\
\text { Non- } \\
\text { Catholic }\end{array}$ & $\begin{array}{c}(4) \\
\text { All BAs }\end{array}$ & $\begin{array}{c}(5) \\
\text { Female } \\
\text { BAs }\end{array}$ & $\begin{array}{c}\text { (6) } \\
\text { All BAs } \\
\text { Non- } \\
\text { Catholic }\end{array}$ \\
\hline Coeducational always & $\begin{array}{c}0.131 \\
(0.0533)\end{array}$ & $\begin{array}{c}0.188 \\
(0.0644)\end{array}$ & $\begin{array}{c}0.180 \\
(0.0592)\end{array}$ & $\begin{array}{c}0.301 \\
(0.0422)\end{array}$ & $\begin{array}{c}0.408 \\
(0.0589)\end{array}$ & $\begin{array}{c}0.279 \\
(0.0467)\end{array}$ \\
\hline $\begin{array}{l}\text { Change to coeducational } \\
\text { before } 1962\end{array}$ & $\begin{array}{c}0.139 \\
(0.0534)\end{array}$ & $\begin{array}{c}0.148 \\
(0.0646)\end{array}$ & $\begin{array}{c}0.191 \\
(0.0599)\end{array}$ & $\begin{array}{c}0.245 \\
(0.0720)\end{array}$ & $\begin{array}{c}0.232 \\
(0.0999)\end{array}$ & $\begin{array}{c}0.221 \\
(0.0778)\end{array}$ \\
\hline $\begin{array}{l}\text { Change to coeducational } \\
\text { from } 1962 \text { to } 1970\end{array}$ & $\begin{array}{c}0.263 \\
(0.0647)\end{array}$ & $\begin{array}{c}0.0975 \\
(0.0782)\end{array}$ & $\begin{array}{c}0.283 \\
(0.0813)\end{array}$ & $\begin{array}{c}0.246 \\
(0.0588)\end{array}$ & $\begin{array}{c}0.223 \\
(0.0819)\end{array}$ & $\begin{array}{c}0.184 \\
(0.0762)\end{array}$ \\
\hline Year open $\times 10^{-2}$ & $\begin{array}{c}0.146 \\
(0.0317)\end{array}$ & $\begin{array}{c}0.178 \\
(0.0383)\end{array}$ & $\begin{array}{c}0.156 \\
(0.0326)\end{array}$ & $\begin{array}{c}0.0797 \\
(0.0435)\end{array}$ & $\begin{array}{c}0.0679 \\
(0.0607)\end{array}$ & $\begin{array}{c}0.0909 \\
(0.0446)\end{array}$ \\
\hline Log (total BAs, 1966) & $\begin{array}{l}-0.106 \\
(0.0140)\end{array}$ & $\begin{array}{l}-0.128 \\
(0.0169)\end{array}$ & $\begin{array}{c}-0.102 \\
(0.0145)\end{array}$ & $\begin{array}{c}-0.139 \\
(0.0173)\end{array}$ & $\begin{array}{l}-0.0784 \\
(0.0241)\end{array}$ & $\begin{array}{l}-0.126 \\
(0.0177)\end{array}$ \\
\hline Public control & $\begin{array}{c}0.388 \\
(0.0314)\end{array}$ & $\begin{array}{c}0.437 \\
(0.0380)\end{array}$ & $\begin{array}{c}0.380 \\
(0.0317)\end{array}$ & $\begin{array}{c}0.427 \\
(0.0373)\end{array}$ & $\begin{array}{c}0.327 \\
(0.0521)\end{array}$ & $\begin{array}{c}0.419 \\
(0.0378)\end{array}$ \\
\hline Protestant denomination & $\begin{array}{l}-0.0808 \\
(0.0308)\end{array}$ & $\begin{array}{l}-0.0670 \\
(0.0373)\end{array}$ & $\begin{array}{l}-0.0802 \\
(0.0313)\end{array}$ & $\begin{array}{l}-0.0828 \\
(0.0369)\end{array}$ & $\begin{array}{c}-0.137 \\
(0.0516)\end{array}$ & $\begin{array}{c}-0.074 \\
(0.0372)\end{array}$ \\
\hline Catholic & $\begin{array}{l}-0.0767 \\
(0.0461)\end{array}$ & $\begin{array}{l}-0.0363 \\
(0.0558)\end{array}$ & & $\begin{array}{c}-0.103 \\
(0.0494)\end{array}$ & $\begin{array}{c}-0.112 \\
(0.0690)\end{array}$ & \\
\hline Constant & $\begin{array}{l}-1.79 \\
(0.610)\end{array}$ & $\begin{array}{l}-2.35 \\
(0.738)\end{array}$ & $\begin{array}{l}-2.01 \\
(0.628)\end{array}$ & $\begin{array}{l}-0.482 \\
(0.854)\end{array}$ & $\begin{array}{l}-0.462 \\
(1.19)\end{array}$ & $\begin{array}{l}-0.734 \\
(0.877)\end{array}$ \\
\hline Region dummies & Yes & Yes & Yes & Yes & Yes & Yes \\
\hline Number of observations & 816 & 816 & 753 & 760 & 753 & 683 \\
\hline$R^{2}$ & 0.389 & 0.372 & 0.394 & 0.370 & 0.250 & 0.354 \\
\hline
\end{tabular}

Sources: BAs by sex for 1966 to 1974 from Web CASPAR, https://webcaspar.nsf.gov/ Other variables are from the 1980 Coeducation College Database (see Appendix).

Notes: The dependent variable is the growth in BAs (the change in the log number of BAs for all BAs, male BAs, female BAs, and those in non-Catholic institutions) from 1966 to 1974. The covariates of greatest interest are whether the school was always coeducational, became coeducational before 1962, switched from 1962 to 1970, measured relative to schools that did not switch through 1970 (the omitted category). "Protestant denomination" includes institutions under any non-Catholic religious control as of 1980 (or as of 1934 for those that failed before 1980). Standard errors are in parentheses. 
Table 7: Role of Coeducation in Women's College Attainment

\begin{tabular}{|c|c|c|c|c|c|}
\hline Dependent variable: & $\begin{array}{c}\text { (1) } \\
\text { Fraction } \\
\text { Coed } \\
\text { Institutions }\end{array}$ & $\begin{array}{c}(2) \\
\text { Fraction } \\
\text { Enrollment in } \\
\text { Coed } \\
\text { Institutions }\end{array}$ & $\begin{array}{l}\text { (3) } \\
\text { Male } \\
\text { College } \\
\text { Rate }\end{array}$ & $\begin{array}{c}\text { (4) } \\
\text { Public High } \\
\text { School } \\
\text { Graduation } \\
\text { Rate or Ratio }\end{array}$ & $R^{2}$ \\
\hline \multicolumn{6}{|l|}{$\begin{array}{l}\text { Female college attendance rate for } \\
\text { cohort } i \text { in year } t \text { in state } j\end{array}$} \\
\hline Cohort is 25 years old in 1920 & & $\begin{array}{c}0.0713 \\
(0.0145)\end{array}$ & $\begin{array}{c}0.684 \\
(0.0890)\end{array}$ & & 0.621 \\
\hline Cohort is 25 years old in 1930 & & $\begin{array}{c}0.0669 \\
(0.0155)\end{array}$ & $\begin{array}{c}0.697 \\
(0.0717)\end{array}$ & & 0.699 \\
\hline Cohort is 25 years old in 1920 & $\begin{array}{c}0.0901 \\
(0.0158)\end{array}$ & & $\begin{array}{c}0.728 \\
(0.0855)\end{array}$ & & 0.661 \\
\hline Cohort is 25 years old in 1930 & $\begin{array}{c}0.0806 \\
(0.0167)\end{array}$ & & $\begin{array}{c}0.745 \\
(0.0710)\end{array}$ & & 0.720 \\
\hline \multicolumn{6}{|l|}{$\begin{array}{l}\text { Female college attendance rate for } \\
\text { cohort } i \text { in year } t \text { in state } j\end{array}$} \\
\hline Cohort is 25 years old in 1920 & & $\begin{array}{c}0.0294 \\
(0.0161)\end{array}$ & $\begin{array}{c}0.292 \\
(0.122)\end{array}$ & $\begin{array}{c}0.296 \\
(0.0719)\end{array}$ & 0.727 \\
\hline Cohort is 25 years old in 1930 & & $\begin{array}{c}0.0288 \\
(0.0166)\end{array}$ & $\begin{array}{c}0.427 \\
(0.0933)\end{array}$ & $\begin{array}{c}0.261 \\
(0.0667)\end{array}$ & 0.777 \\
\hline Cohort is 25 years old in 1920 & $\begin{array}{l}0.0470 \\
(0.179)\end{array}$ & & $\begin{array}{c}0.359 \\
(0.122)\end{array}$ & $\begin{array}{c}0.265 \\
(0.0690)\end{array}$ & 0.746 \\
\hline Cohort is 25 years old in 1930 & $\begin{array}{c}0.0414 \\
(0.0181)\end{array}$ & & $\begin{array}{c}0.472 \\
(0.0963)\end{array}$ & $\begin{array}{c}0.242 \\
(0.0649)\end{array}$ & 0.787 \\
\hline \multicolumn{6}{|l|}{$\begin{array}{l}\text { Female/male college attendance } \\
\text { rate for cohort } i \text { in year } t \text { in state } j\end{array}$} \\
\hline Cohort is 25 years old in 1920 & & $\begin{array}{c}0.573 \\
(0.130)\end{array}$ & & & 0.298 \\
\hline Cohort is 25 years old in 1930 & & $\begin{array}{c}0.363 \\
(0.105)\end{array}$ & & & 0.208 \\
\hline Cohort is 25 years old in 1920 & $\begin{array}{c}0.772 \\
(0.134)\end{array}$ & & & & 0.418 \\
\hline Cohort is 25 years old in 1930 & $\begin{array}{c}0.509 \\
(0.104)\end{array}$ & & & & 0.342 \\
\hline \multicolumn{6}{|l|}{$\begin{array}{l}\text { Female/male college attendance } \\
\text { rate for cohort } i \text { in year } t \text { in state } j\end{array}$} \\
\hline Cohort is 25 years old in 1920 & & $\begin{array}{c}0.520 \\
(0.111)\end{array}$ & & $\begin{array}{c}0.575 \\
(0.133)\end{array}$ & 0.505 \\
\hline Cohort is 25 years old in 1930 & & $\begin{array}{c}0.301 \\
(0.0621)\end{array}$ & & $\begin{array}{c}0.635 \\
(0.0680)\end{array}$ & 0.730 \\
\hline Cohort is 25 years old in 1920 & $\begin{array}{c}0.658 \\
(0.124)\end{array}$ & & & $\begin{array}{c}0.467 \\
(0.0131)\end{array}$ & 0.546 \\
\hline Cohort is 25 years old in 1930 & $\begin{array}{c}0.352 \\
(0.0688)\end{array}$ & & & $\begin{array}{c}0.573 \\
(0.0690)\end{array}$ & 0.740 \\
\hline
\end{tabular}

Goldin and Katz, Coeducation -37- 
Sources: 1934 Coeducation College Database. See Data Appendix. Public secondary school graduation rates by sex were computed from data underlying Goldin (1998).

Notes: All regressions are weighted by the number of men in the cohort. Observations number 48 for all regressions; AK, DC, HI, and PR are excluded. Cohorts are 50 to 59 years old at the time of the census. When $t=1920$, the 1950 census is used; when $t=1930$, the 1960 census is used. Col. (4) uses the contemporaneous public secondary school graduation rate for females by state (that is, the fraction of female 17 year olds graduating secondary school in 1920) or the ratio of the contemporaneous public secondary school graduation rate of females to males. Secondary school graduation rates for 1920 are used in all regressions. Individuals who were 50 to 59 years old in 1960 were 17 years old from 1918 to 1927 and those who were 50 to 59 years old in 1950 were 17 years old from 1908 to 1917. 
Figure 1: Cumulative Number of Schools Opened as Coed and Single-Sex by Year of Opening and Control (1934 sample)

Part A: Opened coed and single-sex for all schools

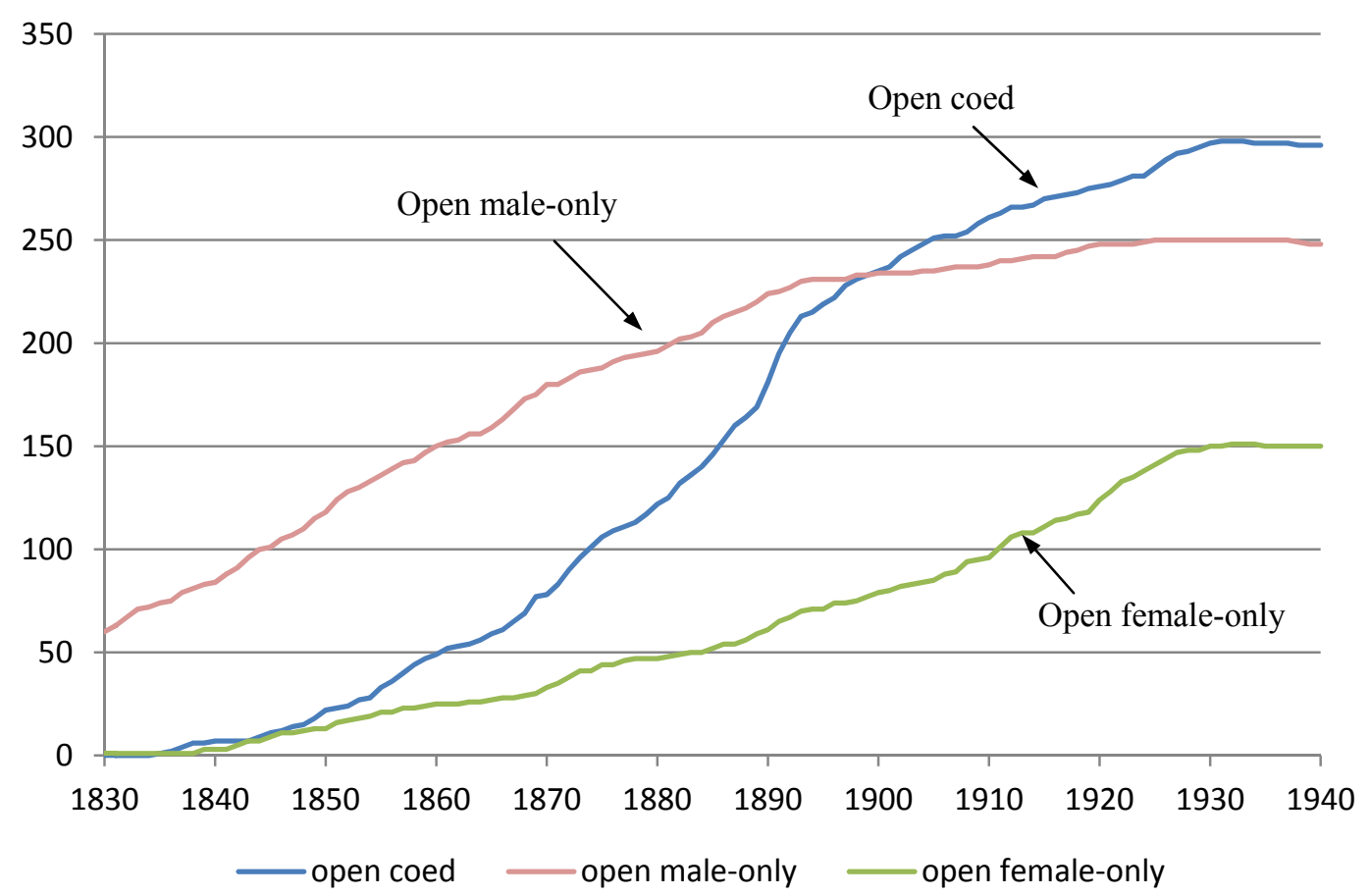

Part B: Opened Coeducational, by Control

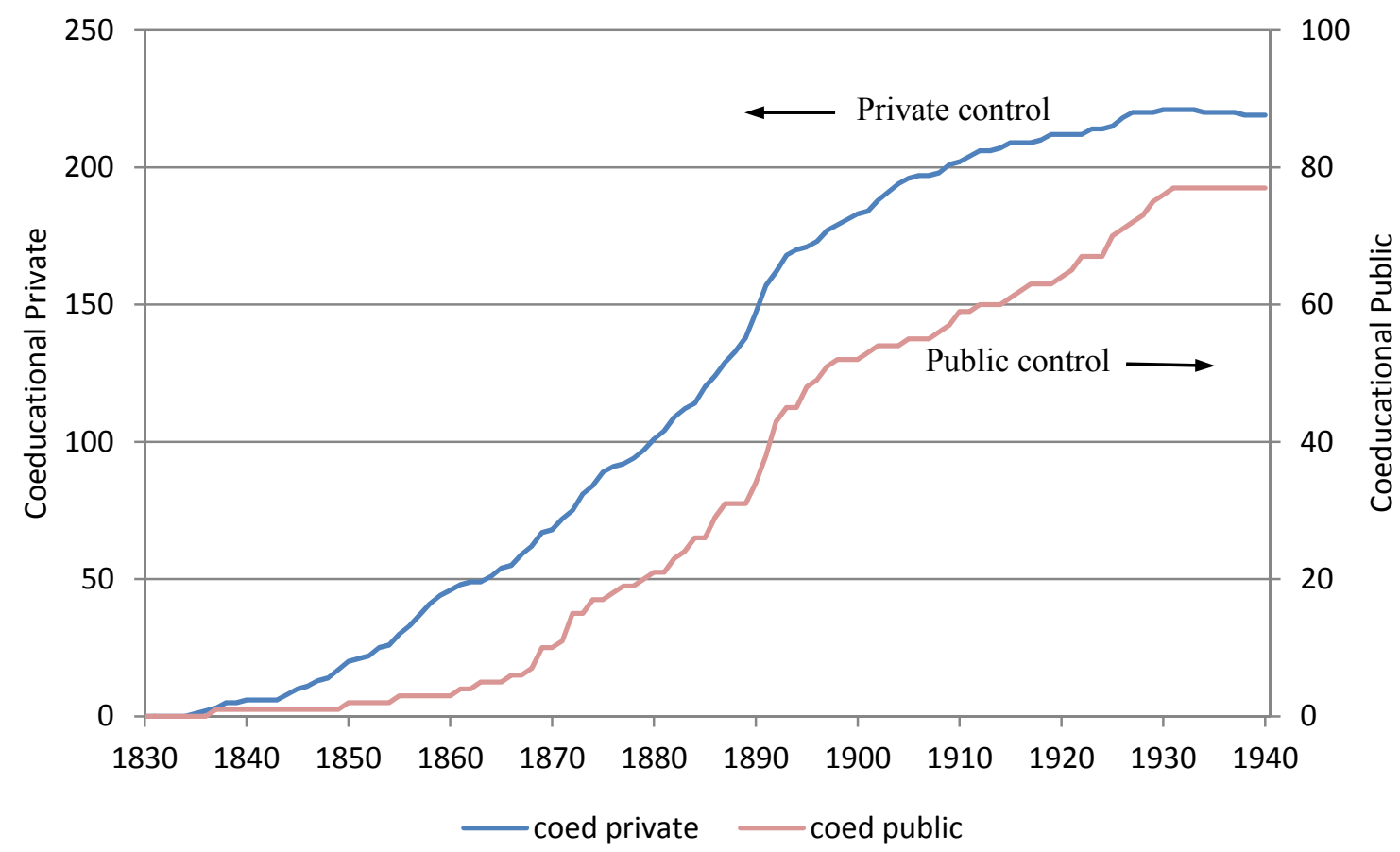

Goldin and Katz, Coeducation -39- 


\section{Part C: Catholic Schools}

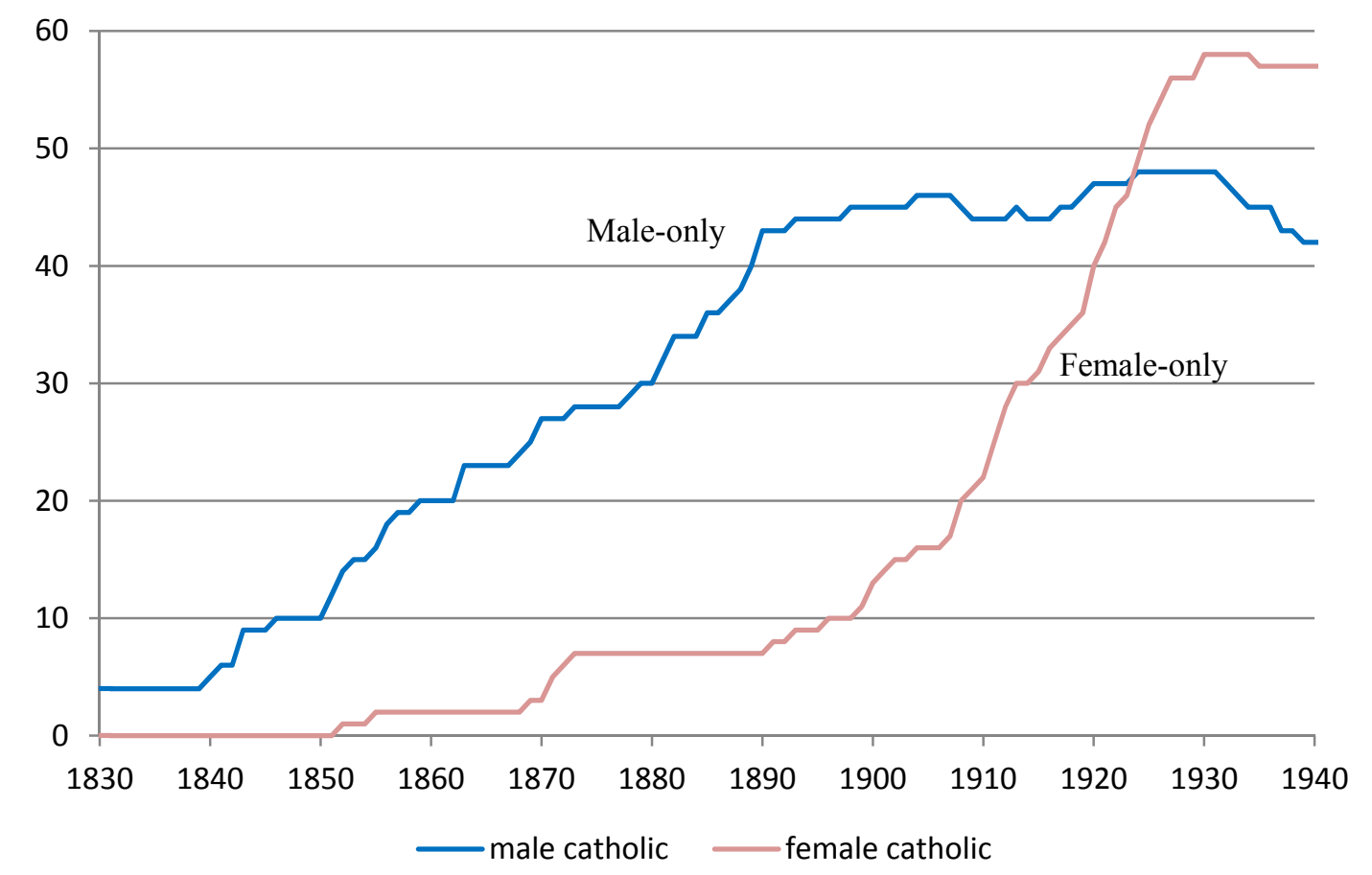

Sources: See Appendix. Data are from the 1934 Coeducation College Database and include institutions that existed in 1897, 1924, or 1934.

Notes: In part B, the data refer to whether the institution opened as a coeducational institution in the private or public sectors. The private control is graphed with respect to the left axis and public control is graphed with respect to the right axis. In part $\mathrm{C}$, the data refer to whether the institution opened as a male-only or female-only Catholic institution. 
Figure 2: Hazard Rate and the Number of Institutions that Switched to Coeducation in the Decade (full sample)

\section{Part A: All Colleges}

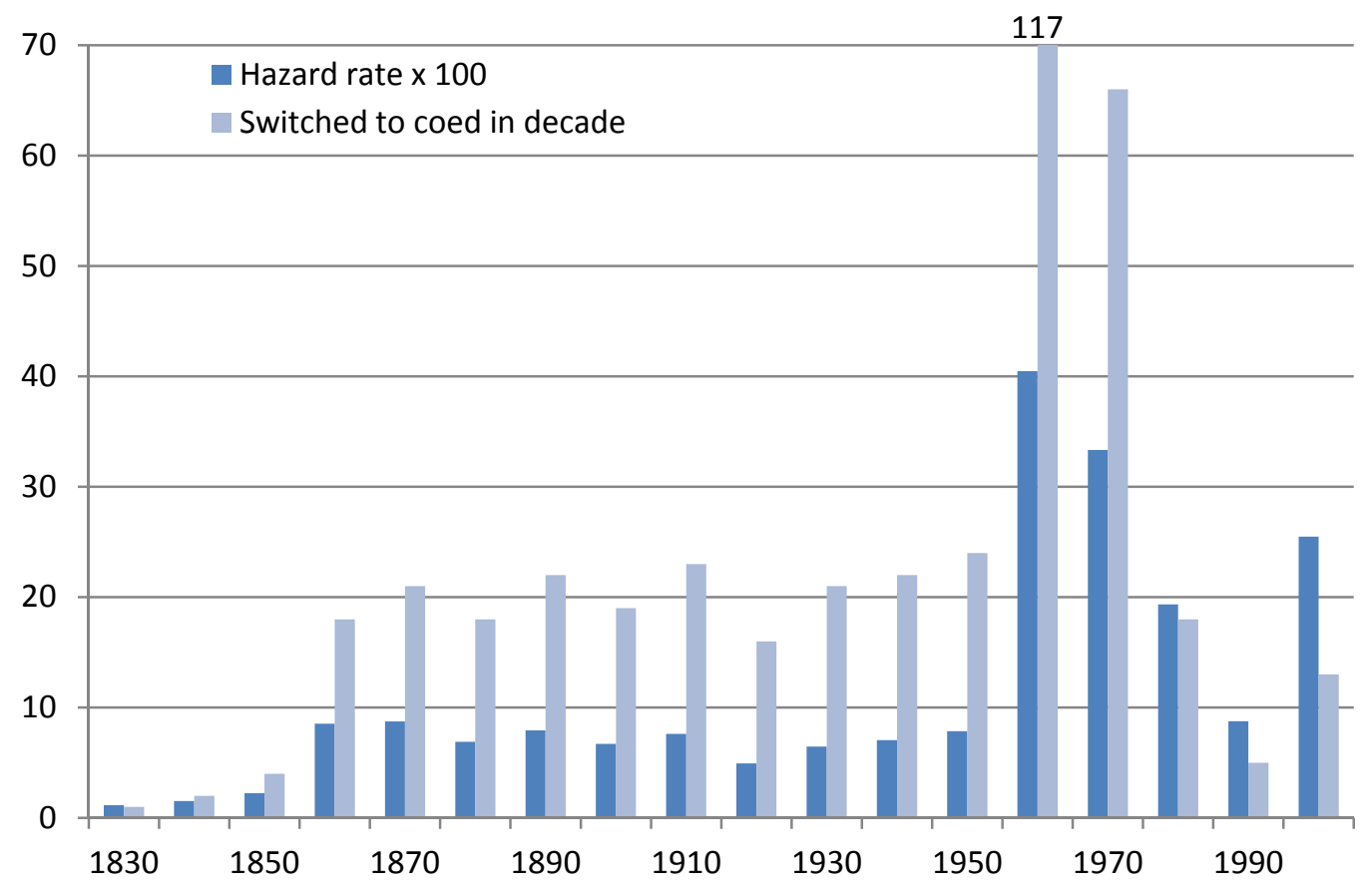

Part B: Men's Non-Catholic Colleges

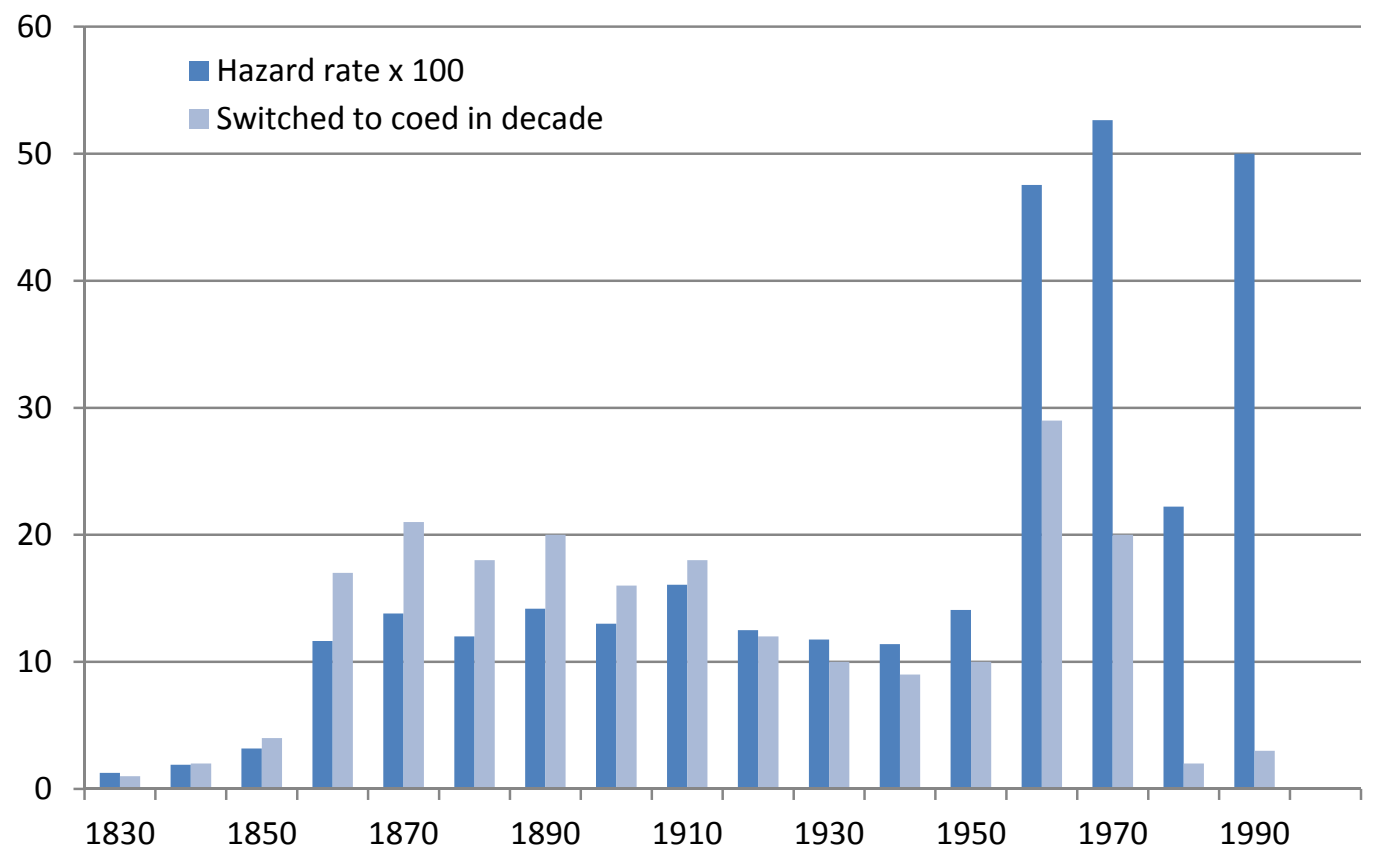

Goldin and Katz, Coeducation -41- 
Sources: See Appendix. The sample used includes all institutions that opened to 1980.

Notes: "Hazard rate $\times 100$ " is the percentage of single-sex institutions (all or male-only) existing at the start of the decade that switched during the decade. "Switched to coed in decade" is the number of single-sex institutions (all or male-only) that switched to coeducational status in the decade given. 
Figure 3: Fraction of Institutions (Existing in 1934) that Were Coeducational by Year Part A: Fraction of All and Non-Catholic Institutions

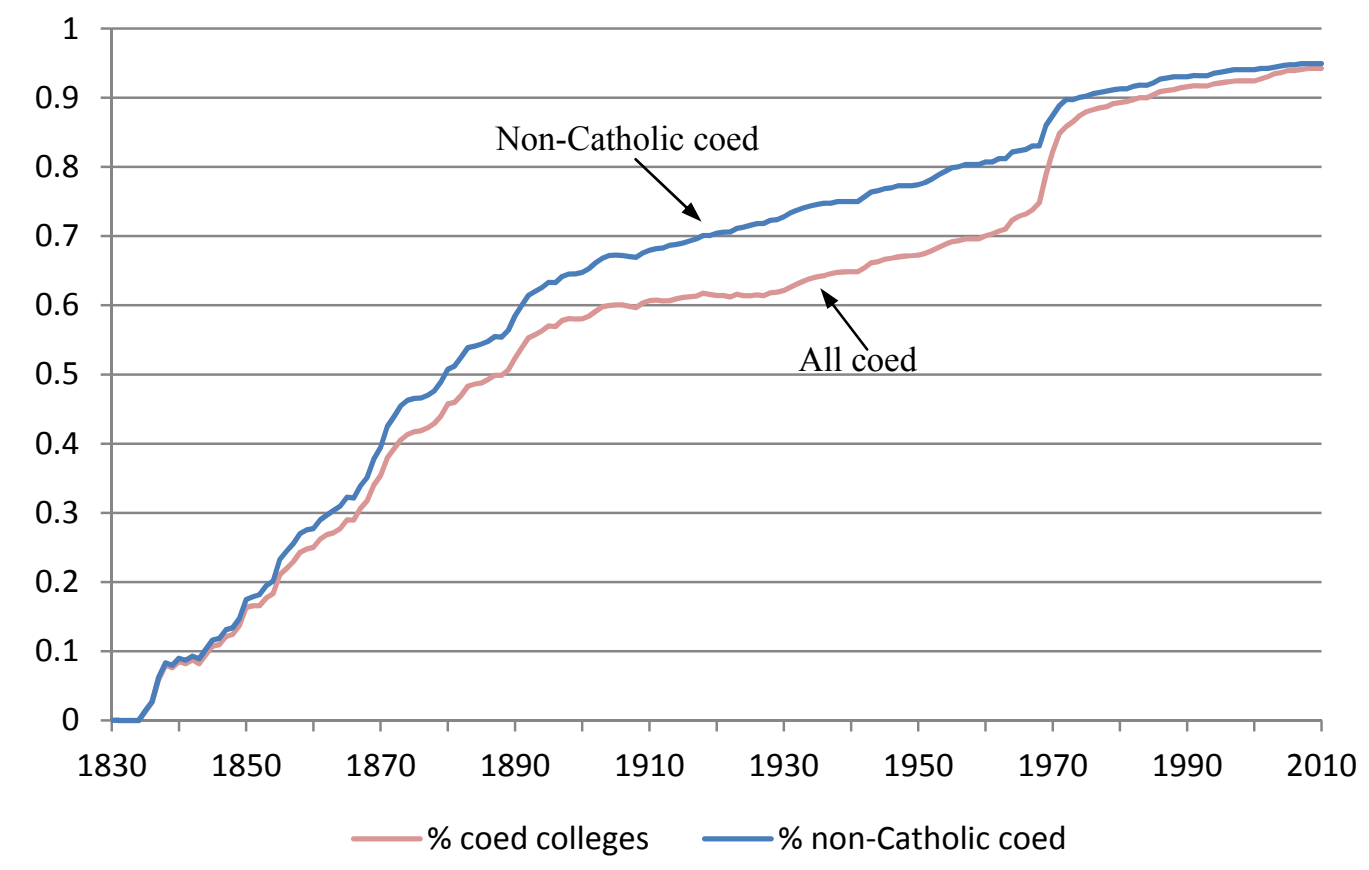

Part B: Fraction of All and Non-Catholic Institutions, Weighted by 1934 Enrollment

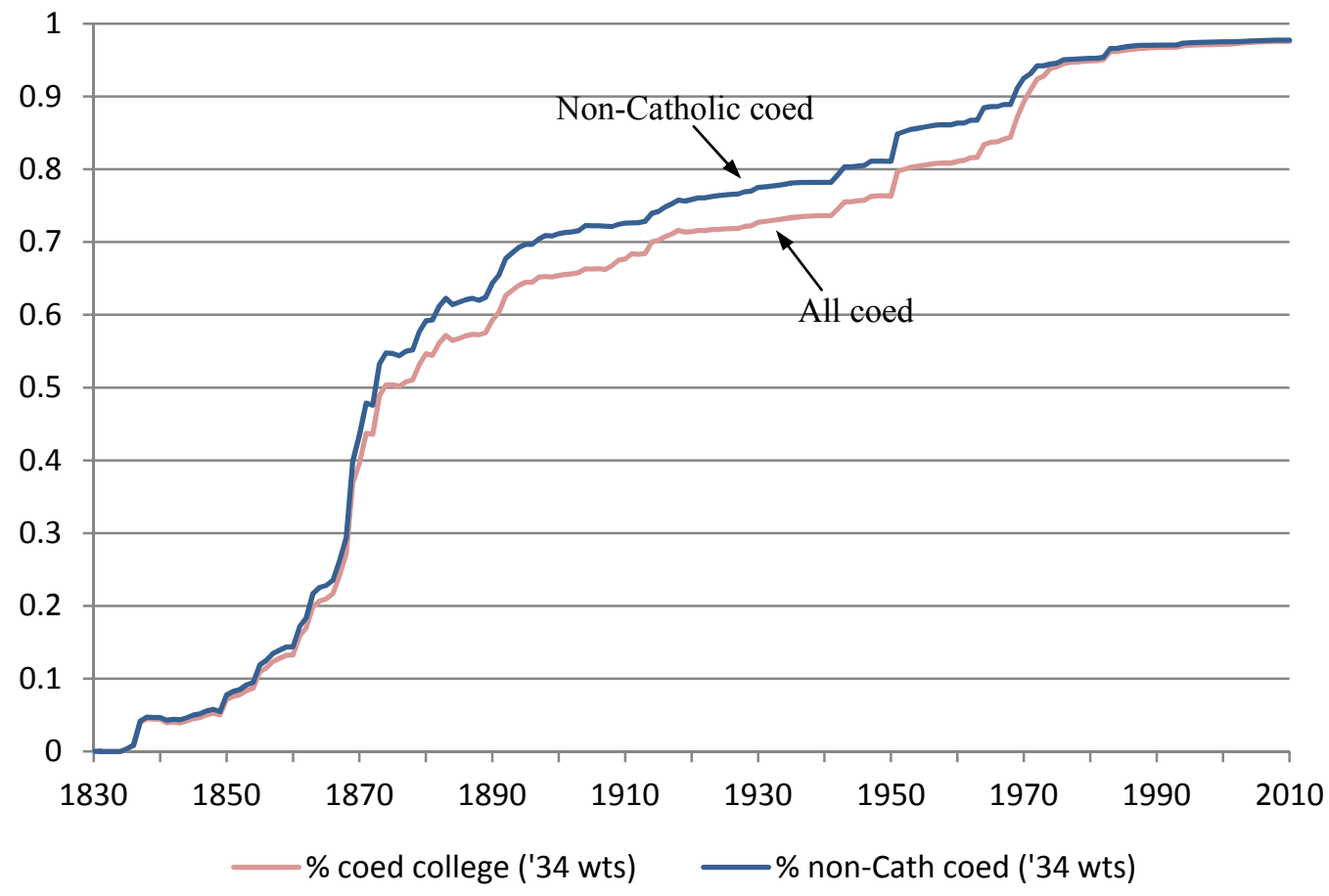

Sources: See Appendix

Goldin and Katz, Coeducation -43- 
Figure 4: The Evolution of Coeducation for Institutions Existing in 1934

Part A: By number of schools

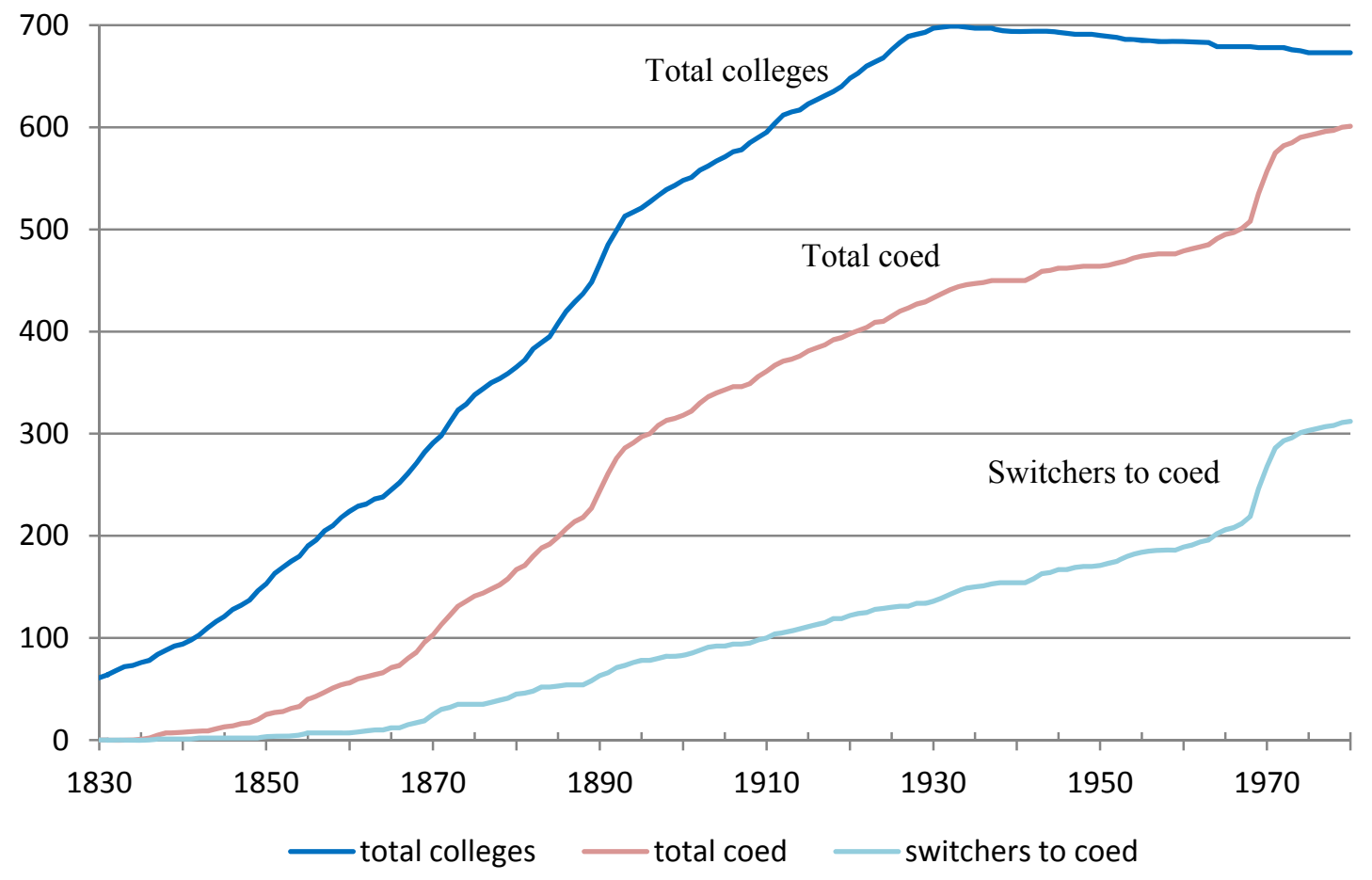

Part B: Number of Non-Catholic Schools

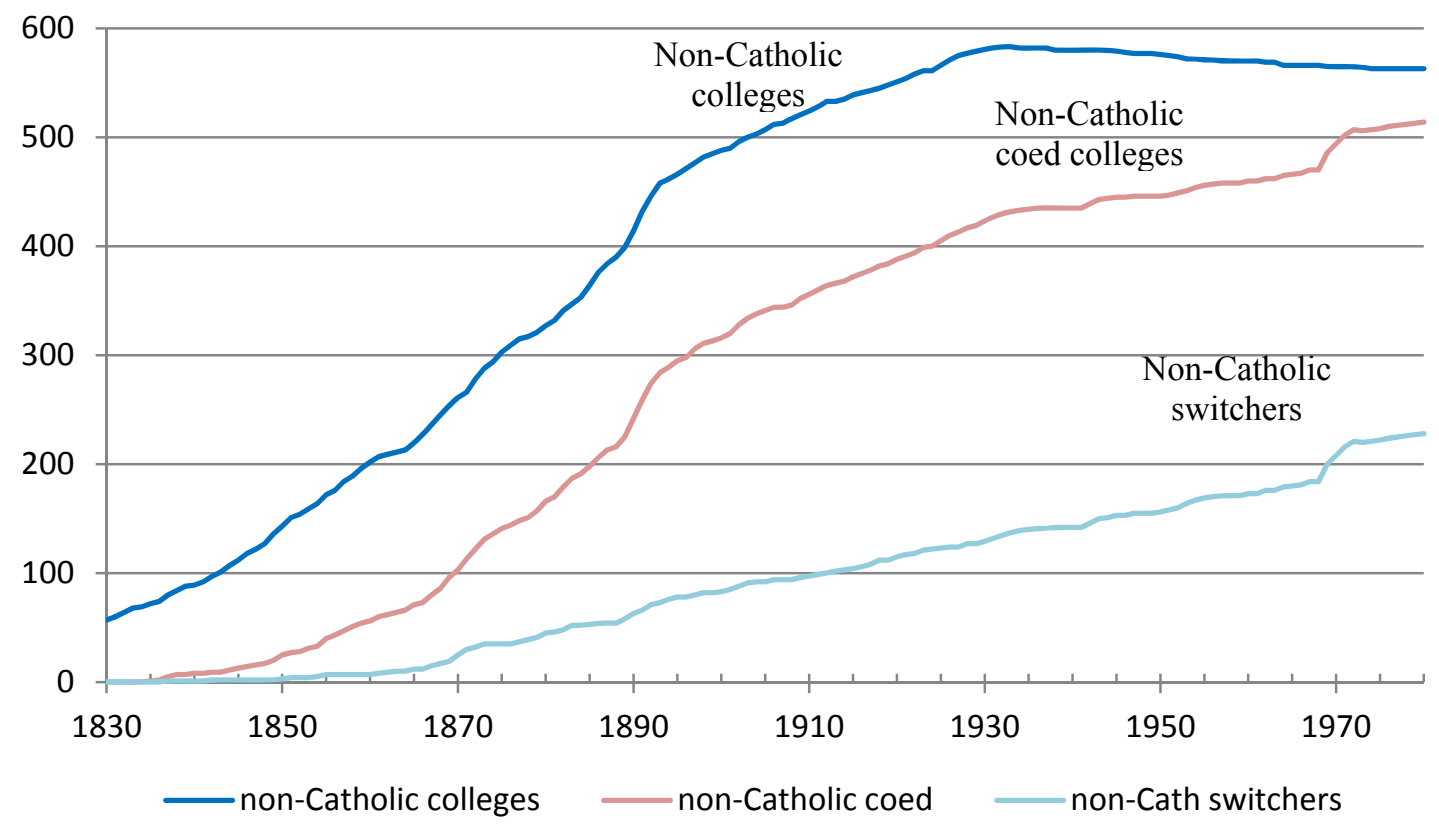

Goldin and Katz, Coeducation -44- 


\section{Part C: Number of Catholic Schools}

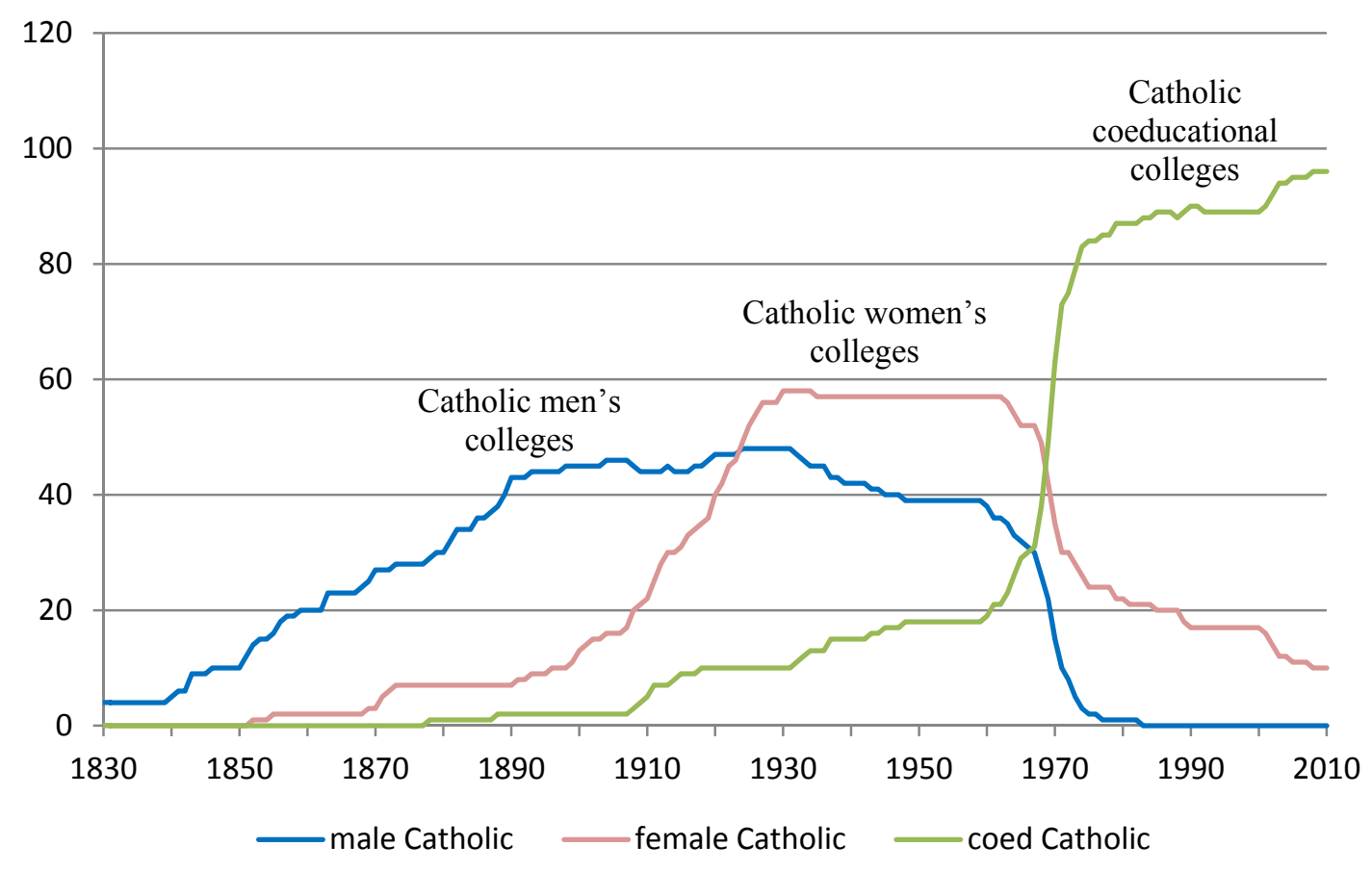

Sources: See Appendix

Goldin and Katz, Coeducation -45- 
Figure 5: Coeducation and Women's College Attainment

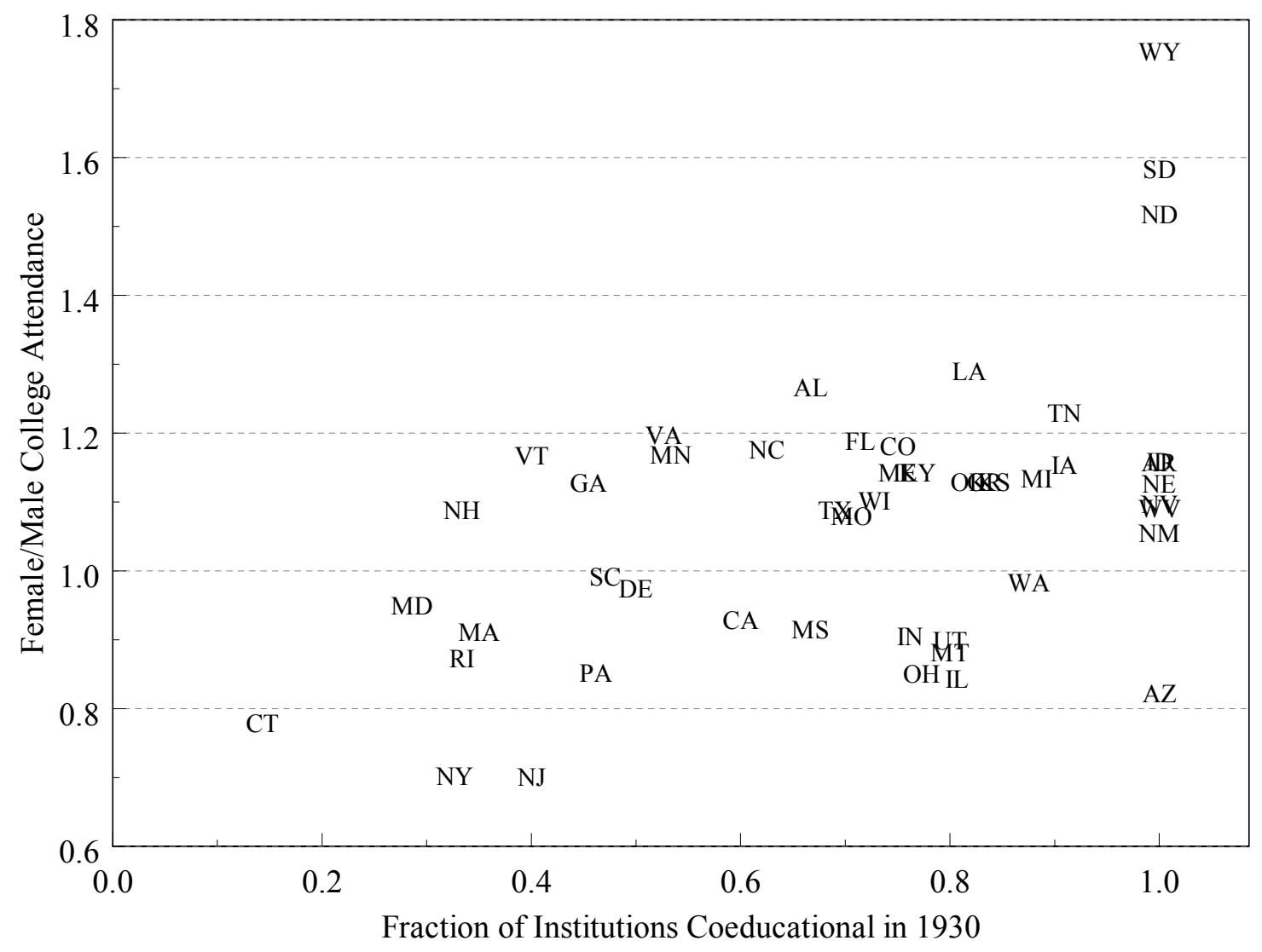

Sources: See Table 7.

Notes: The figure includes individuals 50 to 59 years old in 1960 by state of birth. The regression for these data is: (Female/Male College Attendance) $=0.682+0.509$ (Fraction Institutions Coed in 1930), $\mathrm{R}^{2}=0.342$; number of observations $=48$. The fraction of institutions that were coeducational in 1930 comes from the 1934 Coeducation College Database (see Appendix) and includes institutions that began coeducational and those that switched from single-sex. 


\section{Data Appendix: Coeducation College Database}

A. 1934 Coeducation College Database

Department of the Interior, Commissioner of Education. 1898. Annual Reports of the

Department of the Interior for... 1897, vol. 2. Washington, D.C., G.P.O.

U.S. Office of Education. 1927. Biennial Survey of Education, 1922-24. Bulletin 1926, No. 23. Washington, D.C.: G.P.O.

U.S. Office of Education. 1937. Biennial Survey of Education, 1932-34. Bulletin 1935, No. 2. Washington, D.C.: G.P.O.

Each of the three sources contains relatively similar information on the number of students in various groups (e.g., by sex; by level such as preparatory, undergraduate, and graduate; by type such as collegiate and professional) and revenue sources (e.g., student fees, government grants, private gifts). Total revenues do not include additions to endowment, which are listed separately. Students exclude those in summer school, correspondence courses, extension, and military drill. (Institution-level data, similar to those we have used, are also available in printed form for most years from 1890 to 1938.)

The sample was originally collected for Goldin and Katz (1999) and has been added to and altered to study coeducation. In the original sample, the 1934 data set included 853 institutions, 711 privately-controlled and 142 publicly-controlled. That for 1924 had 790, with 677 private and 113 public. In the 1897 there were 534 universities and colleges and an additional 287 professional, theological, and technical schools not connected to any of those on the original list. The final 1897 sample contains 821 institutions, of which 717 were private and 104 public.

In the 1934 Coeducation College Database, only BA granting institutions are included and dedicated professional and theological schools are generally excluded. These data set restrictions reduce the original number of institutions to 443 in 1897, 631 in 1924, and 704 in 1934. A total of 769 institutions are included, of which 10 are "coordinate" institutions (see below).

When possible, we did not include institutions that were junior colleges in the survey year; separately listed independent teaching colleges and normal schools were also not included. In 1897 a list of "colleges for women, division B" contained some that continued as BA granting institutions and these have been included. More than a hundred of these institutions, however, were probably not real colleges at the time and were not found in later surveys. They have, therefore, been omitted in the analyses. The dedicated professional and theological institutions that did not grant BAs are omitted. It should be noted that a BA granting institution in 1934 may not have granted a BA before 1897, even though our data set will include the institution from its 
opening date.

The 1924 listing contains the "date at first opening," which can differ slightly from the date of founding. We checked these dates against the date of first instruction in American Council on Education (1960). We linked the 1924 schools to those in 1934 and used several other guides, such as The College Blue Book (1933) and Songe (1978), for the histories of institutions that changed city or name, or merged with or split off from others. Of the 790 schools in 1924, 695 were linked to institutions on the 1934 list. Among those that were not theological seminaries and independent professional schools in 1924, the linkage rate was 91.5 percent.

Except in the case of the historically-black institutions, we were able to find virtually all - if not all - publicly-controlled institutions known to have existed in each of the three years: 1897, 1924, and 1934. In both 1897 and 1924 many of the publicly-controlled, historically-black institutions of today were not listed, although some were. We have traced the histories of these institutions and believe they were omitted because they were, correctly, categorized as teaching colleges or industrial institutes. We used the historical information in American Council on Education (1960) for our institutional categorization and were helped by the contemporaneous information in The College Blue Book (1933). There are some anomalies (e.g., Rutgers University) and these are coded as they were in 1934.

The coeducation date variable was added to the institutions in the 1897, 1924, and 1934 data set in the following manner. We defined a coeducational institution as one that had classes for men and women together. These classes had to include the central ones in a liberal arts college and could not be limited to the educational school, for example. We began with lists of coeducational dates created by several other scholars including Janet Currie and Louis Galambos. The majority of our institutions were not on these lists and we obtained those dates using a host of materials. In many cases the date an institution became coeducational was clear. Many of the public institutions, for example, opened as coeducational colleges and universities. But in some cases there was ambiguity and we used our best sense for when the majority of women (or men) could take courses on an equal basis with the men (or women). The date an institution that opened single-sex became coeducational ranges from 1835 to 2008 .

Ten schools reported having a significant number of undergraduate women enrolled in 1934 even though these were male-only institutions at the time. Some of the institutions had true "coordinate" women's colleges (e.g., Brown and Pembroke). In other cases, and these are mainly Catholic colleges and universities, women were admitted to a few undergraduate programs, such as teaching and nursing. We added these true- or pseudo-coordinate institutions to the 1934 data and omitted the women's undergraduate numbers from the male-only institutions. 


\section{B. 1980 Coeducation College Database}

We expanded the data set through time by linking the institutions that existed in 1934 to the Integrated Postsecondary Education Database System (IPEDS). Institutions that were in the IPEDS but not in the 1934 data were those that opened after 1934. Some institutions merged after 1934 and we linked both previous institutions to the new one. We attached FICE codes to the 1934 schools to link the 1980 enrollment figures to the original data set.

The first issue was to match institutions from 1934 to the IPEDS. To maximize the probability of matching a school in the 1934 survey to the IPEDS, we appended the 1980, 1987, 1997, and 2000-2007 IPEDS surveys (see http://nces.ed.gov/ipeds/datacenter/). The institutions

were merged on the basis of name, city, and state. The matches suggested by the algorithm were checked since some institutions changed city and some even changed state. In various cases institutional information was checked on the institution's website to make certain that our match was correct. Of the 769 schools in the original data set, 717 were matched. Those that did not match either closed between 1934 and1980, were music conservatories that are not included in the IPEDS, or had expired before 1934 (but were included in 1924). An additional 766 institutions that opened after 1934 were added to the original data set.

The addition of the 766 institutions to the 1934 list meant that we needed to know when these institutions became coeducational if they opened as a single-sex institution. We used data on BA degrees awarded by sex in 1966 (from NCES CASPAR), the first year available. Our algorithm was that if 95 percent or greater of an institution's degrees went to individuals of a particular sex, we identified the school as single sex. If a school appeared to be single sex in 1966, but was listed as coed in 1980, we examined on-line information about the school to learn when it opened and when it went coed. We did not gather information on the opening dates of the institutions that opened after 1934 because a comprehensive list is not available. 


\section{References}

American Council on Education. 1960. American Universities and Colleges. Edited by Mary Irwin. Washington, D.C.: American Council on Education.

College Blue Book. 1933. The 1933 College Blue Book. Edited by Huber William Hurt and Harriett-Jeanne Hurt. Hollywood by-the-Sea, FL: The College Blue Book.

Conable, Charlotte W. 1977. Women at Cornell: The Myth of Equal Education. Ithaca, NY: Cornell University Press.

Currie, Janet, and Enrico Moretti. 2003. "Mother's Education and the Intergenerational Transmission of Human Capital: Evidence from College Openings," Quarterly Journal of Economics CXVIII (November): 1495-1532.

Department of the Interior, Commissioner of Education. 1898. Annual Reports of the Department of the Interior for... 1897, vol. 2. Washington, D.C., G.P.O.

Eisenmann, Linda. 1997. "Reconsidering a Classic: Assessing the History of Women's Higher Education a Dozen Years after Barbara Solomon," Harvard Educational Review 67 (Winter): 689-718.

Fletcher, Robert S. 1943. A History of Oberlin College. Chicago: R.R. Donnelley and Sons Company.

Gleason, Philip. 2001. "A Half-Century of Change in Catholic Higher Education,” U.S. Catholic Historian 19 (1): 1-19.

Goldin, Claudia. 1998. “America’s Graduation from High School: The Evolution and Spread of Secondary Schooling in the Twentieth Century," Journal of Economic History 58 (June): 34574.

Goldin, Claudia, and Lawrence F. Katz. 1999. "The Shaping of Higher Education: The Formative Years in the United States, 1890 to 1940," Journal of Economic Perspectives 13 (Winter): 37-62.

Goldin, Claudia, and Lawrence F. Katz. 2008. The Race between Education and Technology. Cambridge, MA: Belknap Press for Harvard University.

Graham, Patricia Albjerg. 1978. "Expansion and Exclusion: A History of Women in Higher 
Education,” Signs: Journal of Women in Culture and Society (Summer): 759-73.

Horton Dissent. August 28, 1968. Arthur J. Horton Collection on Coeducation, box no. 4, folder no. 5. Seeley G. Mudd Manuscript Library, Princeton University, Princeton, NJ.

Karabel, Jerome. 2005. The Chosen: The Hidden History of Admission and Exclusion at Harvard, Yale, and Princeton. Boston, MA: Houghton Mifflin.

Marriner, Ernest. 1963. The History of Colby College. Waterville, ME: Colby College Press.

McGuigan, Dorothy Dies. 1970. A Dangerous Experiment: 100 Years of Women at the University of Michigan. Ann Arbor, MI: University of Michigan Press.

Miller-Bernal, Leslie. 2004. “Coeducation: An Uneven Progression.” In Going Coed: Women's Experiences in Formerly Men's Colleges and Universities, 1950-2000, edited by Leslie Miller-Bernal and Susan L. Poulson. Nashville, TN: Vanderbilt University Press.

Miller-Bernal, Leslie and Susan L. Poulson, editors. 2004. Going Coed: Women's Experiences in Formerly Men's Colleges and Universities, 1950-2000. Nashville, TN: Vanderbilt University Press.

Newcomer, Mabel. 1959. A Century of Higher Education for American Women. New York: Harper and Brothers Publishers.

Oreopoulos, Phillip and Kjell G. Salvanes. 2011. "Priceless: The Nonpecuniary Benefits of Schooling," Journal of Economic Perspectives 25 (Winter): 159-84.

Potts, David B. 1992. Wesleyan University, 1831-1910. New Haven, CT: Yale University Press.

Poulson, Susan. 1995. "From Single-Sex to Coeducation: The Advent of Coeducation at Georgetown, 1965-1975," U.S. Catholic Historian (Fall): 117-37.

Radke-Moss, Andrea. 2008. Bright Epoch: Women and Coeducation in the American West. Lincoln: NE: University of Nebraska

Rosenberg, Rosalind. 1988. "The Limits of Access: The History of Coeducation in America." In Women and Higher Education: Essays from the Mount Holyoke College Sesquicentennial Symposia, edited by John Mack Faragher and Florence Howe. New York: W. W. Norton.

Rossi, Alice S. 1987. “Coeducation in a Gender-Stratified Society.” In Educating Men and 
Women Together: Coeducation in a Changing World, edited by Carol Lasser. Urbana and Chicago, IL: University of Illinois Press.

Solomon, Barbara Miller. 1985. In the Company of Educated Women. New Haven, CT: Yale University Press.

Songe, Alice H. 1978. American Universities and Colleges: A Dictionary of Name Changes. Metuchen, NJ: The Scarecrow Press, Inc.

Thomas, M. Carey. 1900. Education of Women. Albany, NY: J.B. Lyon Company.

Turner, Sarah, and William G. Bowen. 1998. "Choice of Major: The Changing (Unchanging) Gender Gap,” Industrial and Labor Relations Review 59 (2): 289-313.

U.S. Office of Education. 1927. Biennial Survey of Education, 1922-24. Bulletin 1926, No. 23. Washington, D.C.: G.P.O.

U.S. Office of Education. 1937. Biennial Survey of Education, 1932-34. Bulletin 1935, No. 2. Washington, D.C.: G.P.O.

Woody, Thomas. 1929. A History of Women's Education in the United States. New York: The Science Press. 